Cochrane Database of Systematic Reviews

\title{
Tramadol with or without paracetamol (acetaminophen) for cancer pain (Review)
}

Wiffen PJ, Derry S, Moore RA

Wiffen PJ, Derry S, Moore RA.

Tramadol with or without paracetamol (acetaminophen) for cancer pain.

Cochrane Database of Systematic Reviews 2017, Issue 5. Art. No.: CD012508.

DOI: 10.1002/14651858.CD012508.pub2.

www.cochranelibrary.com 
TABLE OF CONTENTS

ABSTRACT

PLAIN LANGUAGE SUMMARY

SUMMARY OF FINDINGS

BACKGROUND

OBJECTIVES

METHODS

RESULTS

Figure 1.

Figure 2.

Figure 3.

DISCUSSION

AUTHORS' CONCLUSIONS

ACKNOWLEDGEMENTS

REFERENCES

CHARACTERISTICS OF STUDIES

APPENDICES

WHAT'S NEW

HISTORY

CONTRIBUTIONS OF AUTHORS

DECLARATIONS OF INTEREST

SOURCES OF SUPPORT

DIFFERENCES BETWEEN PROTOCOL AND REVIEW

NOTES

INDEX TERMS 
[Intervention Review]

\section{Tramadol with or without paracetamol (acetaminophen) for cancer pain}

Philip J Wiffen ${ }^{1}$, Sheena Derry², R Andrew Moore ${ }^{3}$

1Thame, UK. ${ }^{2}$ Oxford, UK. ${ }^{3}$ Plymouth, UK

Contact: Philip J Wiffen, Thame, UK. pwiffen@oxfordsrs.org.uk.

Editorial group: Cochrane Pain, Palliative and Supportive Care Group.

Publication status and date: Stable (no update expected for reasons given in 'What's new'), published in Issue 2, 2020.

Citation: Wiffen PJ, Derry S, Moore RA. Tramadol with or without paracetamol (acetaminophen) for cancer pain. Cochrane Database of Systematic Reviews 2017, Issue 5. Art. No.: CD012508. DOI: 10.1002/14651858.CD012508.pub2.

Copyright @ 2020 The Cochrane Collaboration. Published by John Wiley \& Sons, Ltd.

\section{A B S T R A C T}

\section{Background}

Tramadol is an opioid analgesic licensed for use in moderate to severe pain. It is considered as a low risk for abuse, so control regulations are not as stringent as for 'strong' opioids such as morphine. It has a potential role as a step 2 option of the World Health Organization (WHO) analgesic ladder.

\section{Objectives}

To assess the benefits and adverse effects of tramadol with or without paracetamol (acetaminophen) for cancer-related pain.

\section{Search methods}

We searched the following databases using a wide range of search terms: the Cochrane Central Register of Controlled Trials (CENTRAL), MEDLINE, Embase, and LILACS. We also searched three clinical trials registry databases. The date of the last search was 2 November 2016.

\section{Selection criteria}

We selected studies that were randomised, with placebo or active controls, or both, and included a minimum of 10 participants per treatment arm. We were interested particularly in blinded studies, but also included open studies.

We excluded non-randomised studies, studies of experimental pain, case reports, and clinical observations.

\section{Data collection and analysis}

Two review authors independently extracted data using a standard form and checked for agreement before entry into Review Manager 5. We included information about the number of participants treated and demographic details, type of cancer, drug and dosing regimen, study design (placebo or active control) and methods, study duration and follow-up, analgesic outcome measures and results, withdrawals, and adverse events. We collated multiple reports of the same study, so that each study, rather than each report, was the unit of interest in the review. We assessed the evidence using GRADE and created a 'Summary of findings' table.

The main outcomes of interest for benefit were pain reduction of $30 \%$ or greater and $50 \%$ or greater from baseline, participants with pain no worse than mild, and participants feeling much improved or very much improved.

\section{Main results}

We included 10 studies (12 reports) with 958 adult participants. All the studies enrolled participants with chronic malignant tumour-related pain who were experiencing pain intensities described as moderate to severe, with most experiencing at least 4/10 with current treatment. The mean ages were 59 to 70 years, with participants aged between 24 and 87 years. Study length ranged from one day to six months. Five studies used a cross-over design. Tramadol doses ranged from $50 \mathrm{mg}$ as single dose to $600 \mathrm{mg}$ per day; doses of $300 \mathrm{mg}$ per day to 400 mg per day were most common. 
Nine studies were at high risk of bias for one to four criteria (only one high risk of bias for size). We judged all the results to be very low quality evidence because of widespread lack of blinding of outcome assessment, inadequately described sequence generation, allocation concealment, and small numbers of participants and events. Important outcomes were poorly reported. There were eight different active comparators and one comparison with placebo. There was little information available for any comparison and no firm conclusions could be drawn for any outcome.

Single comparisons of oral tramadol with codeine plus paracetamol, of dihydrocodeine, and of rectal versus oral tramadol provided no data for key outcomes. One study used tramadol combined with paracetamol; four participants received this intervention. One study compared tramadol with flupirtine - a drug that is no longer available. One study compared tramadol with placebo and a combination of cobrotoxin, tramadol, and ibuprofen, but the dosing schedule poorly explained.

Two studies (191 participants) compared tramadol with buprenorphine. One study (131 participants) reported a similar proportion of no or mild pain at 14 days.

Three studies (300 participants) compared tramadol with morphine. Only one study, combining tramadol, tramadol plus paracetamol, and paracetamol plus codeine as a single weak-opioid group reported results. Weak opioid produced reduction in pain of at least $30 \%$ from baseline in 55/117 (47\%) participants, compared with 91/110 (82\%) participants with morphine. Weak opioid produced reduction in pain of at least $50 \%$ in $49 / 117$ (42\%) participants, compared with $83 / 110(75 \%)$ participants with morphine.

There was no useful information for any other outcome of benefit or harm.

\section{Authors' conclusions}

There is limited, very low quality, evidence from randomised controlled trials that tramadol produced pain relief in some adults with pain due to cancer and no evidence at all for children. There is very low quality evidence that it is not as effective as morphine. This review does not provide a reliable indication of the likely effect. The likelihood that the effect will be substantially different is very high. The place of tramadol in managing cancer pain and its role as step 2 of the WHO analgesic ladder is unclear.

\section{PLAIN LANGUAGE SUMMARY}

\section{Tramadol with or without paracetamol (acetaminophen) for cancer pain}

\section{Bottom line}

No firm conclusions could be drawn about the effectiveness or harms of tramadol, alone or with paracetamol, in cancer pain.

\section{Background}

One person in two or three who gets cancer will suffer from pain that becomes moderate or severe in intensity. The pain tends to get worse as the cancer progresses.

Tramadol hydrochloride is an opioid analgesic available since 1977. In 2016, tramadol, alone or in combination with paracetamol, was available in products for oral use and by injection from almost 90 companies. Oral formulations include those designed for immediate release, and for modified release over a longer time. Preparations for rectal administration are also available.

In this review, we set out to estimate how well tramadol worked, how many people had side effects, and how severe those side effects were - for example, whether they were so severe that participants stopped taking their tramadol.

\section{Study characteristics}

In November 2016, we found 10 studies with 958 adult participants and no studies in children. The studies were often small and compared different tramadol preparations with different comparator drugs, and did not report important outcomes well. This made it difficult to work out whether tramadol was as good or better or worse than any other drug for cancer pain.

\section{Key findings}

No firm conclusions could be drawn for any outcome in any comparison. Tramadol may not be as good as morphine.

\section{Quality of evidence}

We judged all the evidence available to be of very low quality. This means that the research does not provide a reliable indication of the likely effect. 


\begin{tabular}{|c|c|c|c|c|c|c|c|}
\hline \multirow{11}{*}{ 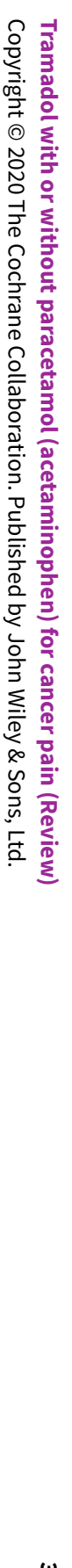 } & \multicolumn{7}{|c|}{$\begin{array}{l}\text { S U M M A R Y O F F I N D I N G S } \\
\text { Summary of findings for the main comparison. Oral tramadol compared with oral morphine for cancer pain }\end{array}$} \\
\hline & \multicolumn{7}{|c|}{ Oral tramadol compared with oral morphine for cancer pain } \\
\hline & \multicolumn{7}{|c|}{$\begin{array}{l}\text { Patient or population: people with pain due to cancer } \\
\text { Settings: any } \\
\text { Intervention: oral tramadol (any dose) } \\
\text { Comparison: oral morphine (any dose) }\end{array}$} \\
\hline & Outcomes & $\begin{array}{l}\text { Probable out- } \\
\text { come with } \\
\text { tramadol }\end{array}$ & $\begin{array}{l}\text { Probable out- } \\
\text { come with } \\
\text { morphine }\end{array}$ & $\begin{array}{l}\text { Relative effect } \\
(95 \% \mathrm{Cl})\end{array}$ & $\begin{array}{l}\text { No of partici- } \\
\text { pants } \\
\text { (studies) }\end{array}$ & $\begin{array}{l}\text { Quality of the } \\
\text { evidence } \\
\text { (GRADE) }\end{array}$ & Comments \\
\hline & $\begin{array}{l}\text { Participants with pain } \\
\text { reduction of } 30 \% \text { or } \\
\text { greater from baseline }\end{array}$ & $55 / 117(47 \%)$ & $91 / 110(82 \%)$ & Not calculated & $\begin{array}{l}227 \\
\text { (1 study) }\end{array}$ & Very low quality & $\begin{array}{l}1 \text { study reporting on tramadol, tramadol + } \\
\text { paracetamol and codeine + paracetamol. }\end{array}$ \\
\hline & $\begin{array}{l}\text { Participants with pain } \\
\text { reduction of } 50 \% \text { or } \\
\text { greater from baseline }\end{array}$ & $49 / 117(42 \%)$ & $83 / 110(75 \%)$ & Not calculated & $\begin{array}{l}227 \\
\text { (1 study) }\end{array}$ & Very low quality & $\begin{array}{l}1 \text { study reporting on tramadol, tramadol + } \\
\text { paracetamol and codeine + paracetamol. }\end{array}$ \\
\hline & $\begin{array}{l}\text { Participants with pain no } \\
\text { worse than mild }\end{array}$ & No data & & Not calculated & $\begin{array}{l}227 \\
\text { (1 study) }\end{array}$ & Very low quality & $\begin{array}{l}1 \text { study reporting on tramadol, tramadol + } \\
\text { paracetamol and codeine + paracetamol. }\end{array}$ \\
\hline & $\begin{array}{l}\text { Participants with PGIC of } \\
\text { much improved or very } \\
\text { much improved }\end{array}$ & No data & & Not calculated & $\begin{array}{l}227 \\
\text { (1 study) }\end{array}$ & Very low quality & $\begin{array}{l}1 \text { study reporting on tramadol, tramadol + } \\
\text { paracetamol and codeine + paracetamol. }\end{array}$ \\
\hline & $\begin{array}{l}\text { Serious adverse events } \\
\text { (death) }\end{array}$ & $3 / 142$ & $3 / 138$ & Not calculated & $\begin{array}{l}280 \\
\text { (2 studies) }\end{array}$ & Very low quality & $\begin{array}{l}1 \text { of the } 2 \text { studies reported on tramadol, tra- } \\
\text { madol + paracetamol and codeine + parac- } \\
\text { etamol. }\end{array}$ \\
\hline & Other adverse events & No analysis pos & & Not calculated & & Very low quality & $\begin{array}{l}\text { Inconsistent reporting between studies and } \\
\text { comparators. }\end{array}$ \\
\hline & Withdrawals & No analysis pos & & Not calculated & & Very low quality & $\begin{array}{l}\text { Inconsistent reporting between studies and } \\
\text { comparators. }\end{array}$ \\
\hline
\end{tabular}


Descriptors for levels of evidence (EPOC 2015):

High quality: This research provides a very good indication of the likely effect. The likelihood that the effect will be substantially different ${ }^{\dagger}$ is low.

Moderate quality: This research provides a good indication of the likely effect. The likelihood that the effect will be substantially different ${ }^{\dagger}$ is moderate.

Low quality: This research provides some indication of the likely effect. However, the likelihood that it will be substantially different ${ }^{\dagger}$ is high

Very low quality: This research does not provide a reliable indication of the likely effect. The likelihood that the effect will be substantially different ${ }^{\dagger}$ is very high

† Substantially different: a large enough difference that it might affect a decision. 


\section{B A C K G R O U N D}

This review is one of a suite of reviews on the efficacy and safety of opioid medicines to treat cancer pain. These include reviews on buprenorphine (Schmidt-Hansen 2015a), fentanyl (Hadley 2013), hydromorphone (Bao 2016), oxycodone (Schmidt-Hansen 2015b), methadone (Nicholson 2017), morphine (Wiffen 2016), and tapentadol (Wiffen 2015).

\section{Description of the condition}

Cancer is estimated to cause over eight million deaths per annum - approximately $13 \%$ of deaths worldwide (IARC 2012). Globally, 32 million people are living with cancer. In the UK alone in 2014, there were around 350,000 new cases of cancer annually, with around $50 \%$ of people surviving for 10 years or more after diagnosis (Cancer Research UK 2016).

Cancer pain is perhaps one of the most feared symptoms associated with the disease. Pain may be the first symptom to cause someone to seek medical advice that leads to a diagnosis of cancer and $30 \%$ to $50 \%$ of all people with cancer will experience moderate to severe pain at some time (Portenoy 1999). Pain can occur at any time as the disease progresses but the frequency and intensity of pain tends to increase as the cancer advances (Portenoy 1999; van den Beuken-van Everdingen 2016). For people with advanced cancer, some $75 \%$ to $90 \%$ will experience pain having a major impact on daily living (Wiffen 2013). Pain had a significant negative correlation with quality of life $(\mathrm{Q} O \mathrm{~L})$ in studies of people with cancer in China, Japan, and Palestine, for example (Deng 2012; Dreidi 2016; Mikan 2016). Studies indicate that approximately $40 \%$ of patients suffered pain after curative treatment, 55\% during cancer treatment and $66 \%$ in advanced disease and pain related to cancer is frequently described as distressing or intolerable by more than one third of patients (Breivik 2009; van den Beuken-van Everdingen 2016).

Cancer pain can be the result of the cancer itself, interventions to treat the cancer, and sometimes other underlying pains. Prevalence is also linked to cancer type, with head and neck cancer showing the highest prevalence. Age also has an impact with younger patients experiencing more pain (Prommer 2015). For this review, we will not consider postsurgical pain related to surgery or neuropathic pains due to chemotherapy.

The current World Health Organization (WHO) cancer pain ladder for adults recommends the use of weak opioids, with or without non-opioid analgesics, as the second step on the ladder (WHO 2016). The current National Institute for Health and Care Excellence in the UK advises that non-opioid analgesics alone be used for treating mild pain ( 0 to 3 on a 0 to 10 pain scale), together with a weak opioid for such as codeine or tramadol for mild to moderate pain (3 to 6), and with a strong opioid such as morphine for severe pain (6 to 10) (NICE 2016).

The effectiveness of the WHO cancer pain ladder has been examined from available evidence several times since the mid-1990s. These studies reported varying degrees of success, typically between $20 \%$ and $100 \%$ of people with cancer pain achieving good relief (Azevedo São Leão Ferreira 2006; Carlson 2016; Jadad 1995), with some suggesting that as many as $50 \%$ of people with cancer pain are under treated (Deandrea 2008). Some authorities have suggested that the second step on the ladder could be removed, and replaced with low doses of strong opioids such as morphine (Twycross 2014), which is currently the start of the third step.

\section{Description of the intervention}

Tramadol hydrochloride is an opioid analgesic originally marketed in West Germany in 1977. In 2016, tramadol, alone or in combination with paracetamol (acetaminophen), was available in products for oral use and by injection from almost 90 companies. Oral formulations include those designed for immediate release, and for modified release over a longer time. Preparations for rectal and parenteral administration are also available. The total oral daily dosage is usually up to $400 \mathrm{mg}$, although some licenses state that $400 \mathrm{mg}$ is the maximum dose (Martindale 2016).

When combined with paracetamol, daily dosage is typically a maximum of eight tablets, each containing tramadol $37.5 \mathrm{mg}$ and paracetamol $325 \mathrm{mg}$.

Tramadol is used to treat a range of different pain conditions. Tramadol differs from traditional opioids in not only acting as a $\mu$-opioid agonist, but also having a range of other properties that may contribute to its analgesic effect, including serotonin reuptake inhibition and noradrenaline reuptake inhibition. It is licensed for use in moderate to severe pain and is less potent than morphine or similar drugs. It is considered to fit into step 2 of the WHO analgesic ladder (WHO 2016). In some parts of the world, tramadol is classified as a controlled substance (similar to codeine in this respect), but the exact classification and controls on prescribing vary markedly.

Tramadol has reasonable efficacy in acute postoperative pain as a single agent, and in combination with paracetamol (Edwards 2002; Moore 1997). It probably also has efficacy in neuropathic pain conditions (Hollingshead 2006), but has small benefits in osteoarthritis (Cepeda 2006). One previous systematic review concluded that the evidence base for tramadol was inadequate to recommend it as an alternative to paracetamol plus codeine for routine use in people with mild to moderate cancer pain (Tassinari 2011).

Tramadol is associated with typical opioid adverse events of nausea, dizziness, and dry mouth, although vomiting and constipation are thought to be less of a problem than with traditional opioids. Use of tramadol with concurrent serotonergic therapy poses a risk of serotonin syndrome (Beakley 2015).

Like other opioids, tramadol is subject to abuse. One study in Germany (looking at data from 1990 to 2009), where tramadol is not scheduled in the German Narcotic Drugs Act, calculated the incidence of abuse as 0.21 cases per million defined daily dosages (DDDs) and the incidence of dependency as 0.12 cases per million DDDs, with lower incidences in recent years (Radbruch 2013). The conclusion was that tramadol had a low potential for misuse, abuse, and dependency.

\section{How the intervention might work}

Tramadol is a synthetic 4-phenyl-piperidine analogue of codeine with a central analgesic effect. Both tramadol and its O-desmethyl metabolite are selective, weak OP3-receptor $(\mu)$ agonists. The mode of action is poorly understood (Minami 2015; Reeves 2008). 
Tramadol is metabolised by $\mathrm{N}$ - and O-demethylation via the cytochrome P450 isoenzymes CYP3A4 and CYP2D6 and glucuronidation or sulphation in the liver. Around $40 \%$ of the analgesic action of tramadol is provided by $\mathrm{O}$-desmethyl tramadol (M1) created by rapid metabolism of tramadol in the liver via CYP2D6 (Bozkurt 2005; Grond 2004; Lintz 1998). Tramadol is also metabolised by N-demethylation via CYP3A4, and glucuronidation or sulphation in the liver (Grond 2004).

Tramadol is available as a racaemic mixture of $(+)$ and $(-)$ enantiomers. The $(+)$ enantiomer has only a weak affinity to $\mu$ opioid receptors and inhibits serotonin reuptake, while the (-) enantiomer inhibits noradrenaline reuptake in the spinal cord (Bozkurt 2005; Scott 2000). These different modes action might explain the longer analgesic efficacy and the lower incidence of opioid adverse effects, but a range of other modes of action have been proposed (Bozkurt 2005; Grond 2004).

Tramadol is rapidly absorbed after oral administration and has an absolute bioavailability of $65 \%$ to $70 \%$ (Lintz 1998; Scott 2000). Generally, there are no significant differences in the pharmacokinetics (elimination half-life, distribution, serum clearance, and concentration of metabolites) of tramadol between adults and children after oral dosing or intravenous injection. Genetic variances probably influence analgesic efficacy (Gan 2007). About $8 \%$ of the white population has CYP2D 6 deficiency that reduces the analgesic effects of tramadol, and this may well be greater in some other populations (Pedersen 2005). Other drugs metabolised by CYP2D6 enzymes (e.g. ondansetron) can potentially interfere with tramadol metabolism, changing how well it works in individuals, and possible adverse events.

\section{Why it is important to do this review}

In many countries, strong opioids such as morphine are severely restricted, if available at all, and with wide variation in per capita use (see Pain \& Policy Studies Group at University of MadisonWisconsin; www.painpolicy.wisc.edu/opioid-consumption-data). This leaves many people with cancer at the risk of severe lifelimiting pain. If tramadol, with or without paracetamol, is effective, it may provide an alternative for people with moderate to severe cancer pain. This review will inform policy makers such as the WHO on the possible utility of tramadol to treat cancer-related pain. It is hoped that the review will inform patients and carers on the value or otherwise of tramadol in this context.

A previous systematic review examined only oral tramadol, not the combination with paracetamol, included observational studies as well as randomised trials, and is now out of date (Tassinari 2011). Therefore, a new systematic review concentrating on randomised trial evidence is appropriate.

\section{O B JE C T I VES}

To assess the benefits and adverse effects of tramadol with or without paracetamol (acetaminophen) for cancer-related pain.

\section{METHODS}

\section{Criteria for considering studies for this review}

\section{Types of studies}

We included studies if they:
- were randomised (described as 'randomised' anywhere in the manuscript);

- ideally were double blind, but we also included open studies;

- had placebo or active controls, or both;

- included a minimum of 10 participants per treatment arm.

We excluded non-randomised studies, studies of experimental pain, case reports, and clinical observations. We included only studies that were fully published or available as extended abstracts (e.g. from clinical trials websites); we did not include short (usually conference) abstracts as these are often unreliable (PaPaS 2012).

\section{Types of participants}

Studies could include adults or children of any age who experienced cancer-related pain.

\section{Types of interventions}

Tramadol with or without paracetamol for cancer pain. Tramadol could be administered at any dose and by any route, and compared to placebo or any active comparator.

\section{Types of outcome measures}

Pain had to be measured using a validated assessment tool. For pain intensity, for example, this could be a $100-\mathrm{mm}$ visual analogue scale (VAS) or 11-point numerical rating scale (no pain to worst pain imaginable) or a 4-point categorical scale (none, mild, moderate, severe), and for pain relief a 100-mm VAS (no relief to complete relief), or 5-point categorical scale (none, a little, some, a lot, complete or words to that effect). Measures of $30 \%$ or greater (moderate) and $50 \%$ or greater (substantial) reduction of pain over baseline are recommended outcomes for chronic pain studies from the Initiative on Methods, Measurement, and Pain Assessment in Clinical Trials (IMMPACT) (Dworkin 2008). When considering Patient Global Impression of Change (PGIC), 30\% or greater reduction of pain over baseline equates to much improved or very much improved, and $50 \%$ or greater reduction of pain over baseline equates to very much improved. We also used results equivalent to no pain or mild pain, because these are also outcomes acceptable to people with various types of pain (Moore 2013).

\section{Primary outcomes}

- Number of participants with pain reduction of $30 \%$ or greater from baseline.

- Number of participants with pain reduction of $50 \%$ or greater from baseline.

- Number of participants with pain no worse than mild (Moore 2013).

- Number of participants with PGIC of much improved or very much improved (or equivalent wording).

\section{Secondary outcomes}

- Quality of life (QoL).

- Use of rescue medication.

- Participant satisfaction or preference.

- Serious adverse events, including death.

- Other adverse events, particularly reports of effects of treatment on somnolence, appetite, or thirst (Wiffen 2014).

- Attrition: withdrawals due to lack of efficacy or adverse events. 


\section{Search methods for identification of studies}

\section{Electronic searches}

We searched the following databases without language or date restrictions.

- The Cochrane Central Register of Controlled Trials (CENTRAL) (via CRSO on 2 November 2016).

- MEDLINE (via Ovid, from 1947 to 2 November 2016).

- Embase (via Ovid, from 1974 to 2 November 2016).

- LILACS (via Birme, searched up to 2 November 2016).

We used a combination of Medical subject headings (MeSH), or equivalent, and text word terms and tailored search strategies to individual databases. The search strategies are in Appendix 1, Appendix 2, Appendix 3, and Appendix 4.

\section{Searching other resources}

We searched the metaRegister of controlled trials (mRCT) (www.controlled-trials.com/mrct), ClinicalTrials.gov (www.clinicaltrials.gov), and the WHO International Clinical Trials Registry Platform (ICTRP) (apps.who.int/trialsearch/) for unpublished (in journals) and ongoing trials. In addition, we checked the reference lists of reviews and retrieved articles for additional studies and performed citation searches on key articles. We planned to contact authors where necessary for additional information but we judged this to be unnecessary.

\section{Data collection and analysis}

\section{Selection of studies}

Two review authors (PW, SD) independently read the abstract of each study identified by the search, eliminated studies that clearly did not satisfy inclusion criteria, and obtained full copies of the remaining studies. Two review authors (PW, SD) independently read these studies to select relevant studies for inclusion, and, in the event of disagreement, a third review author (RAM) adjudicated. We did not anonymise the studies before assessment. We have included a Preferred Reporting Items for Systematic Reviews and Meta-Analyses (PRISMA) flow chart to show the status of identified studies (Moher 2009) as recommended in Part 2, Section 11.2.1 of the Cochrane Handbook for Systematic Reviews of Interventions (Higgins 2011). We included studies in the review irrespective of whether they reported measured outcome data in a 'usable' way.

\section{Data extraction and management}

Two review authors (PW, SD) independently extracted data using a standard form and checked for agreement before entry into Review Manager 5 (RevMan 5) (RevMan 2014). We included information about the number of participants treated and demographic details, type of cancer, drug and dosing regimen, study design (placebo or active control) and methods, study duration and follow-up, analgesic outcome measures and results, withdrawals, and adverse events. We collated multiple reports of the same study, so that each study, rather than each report, was the unit of interest in the review. We collected characteristics of the included studies in sufficient detail to complete a 'Characteristics of included studies' table.

\section{Assessment of risk of bias in included studies}

Two review authors (PW, SD) independently assessed risk of bias for each study, using the criteria outlined in the Cochrane Handbook for Systematic Reviews of Interventions (Chapter 8, Higgins 2011), and adapted from those used by the Cochrane Pregnancy and Childbirth Group, with any disagreements resolved by discussion. We completed a 'Risk of bias' table for each included study using the 'Risk of bias' tool in RevMan 5 (RevMan 2014).

We assessed the following for each study.

- Random sequence generation (checking for possible selection bias). We assessed the method used to generate the allocation sequence as: low risk of bias (any truly random process, e.g. random number table; computer random number generator); unclear risk of bias (method used to generate sequence not clearly stated). We excluded studies using a non-random process (e.g. odd or even date of birth; hospital or clinic record number).

- Allocation concealment (checking for possible selection bias). The method used to conceal allocation to interventions prior to assignment determines whether intervention allocation could have been foreseen in advance of, or during, recruitment, or changed after assignment. We assessed the methods as: low risk of bias (e.g. telephone or central randomisation; consecutively numbered sealed opaque envelopes); unclear risk of bias (method not clearly stated). We excluded studies that did not conceal allocation (e.g. open list).

- Blinding of participants and personnel (checking for possible performance bias). We assessed the methods used to blind study participants and personnel from knowledge of which intervention a participant received. We assessed methods as: low risk of bias (study stated that it was blinded and described the method used to achieve blinding, such as identical tablets matched in appearance or smell, or a doubledummy technique); unclear risk of bias (study stated that it was blinded but did not provide an adequate description of how it was achieved); high risk of bias (study was not blinded).

- Blinding of outcome assessment (checking for possible detection bias). We assessed the methods used to blind study participants and outcome assessors from knowledge of which intervention a participant received. We assessed the methods as: low risk of bias (study had a clear statement that outcome assessors were unaware of treatment allocation, and ideally described how this was achieved); unclear risk of bias (study stated that outcome assessors were blind to treatment allocation but lacked a clear statement on how it was achieved); high risk of bias (study was not blinded).

- Incomplete outcome data (checking for possible attrition bias due to the amount, nature, and handling of incomplete outcome data). We assessed the methods used to deal with incomplete data as: low risk of bias (less than $10 \%$ of participants did not complete the study or used 'baseline observation carried forward' analysis, or both); unclear risk of bias (used 'last observation carried forward' (LOCF) analysis); high risk of bias (used 'completer' analysis).

- Selective reporting (reporting bias). We assessed the risk of reporting bias as: low risk of bias (all intended outcomes reported); unclear risk of bias (any anomaly in reporting, such as participants contributing more than one set of data, or some outcomes not participant-reported); high risk of bias (prespecified outcome of interest not reported). 
- Size of study (checking for possible biases confounded by small size). We assessed studies as being at low risk of bias (200 participants or more per treatment arm); unclear risk of bias (50 to 199 participants per treatment arm); high risk of bias (fewer than 50 participants per treatment arm).

\section{Measures of treatment effect}

We planned to use dichotomous data to calculate risk ratios (RR) with $95 \%$ confidence intervals $(\mathrm{Cl})$ using a fixed-effect model, and calculate numbers needed to treat for one additional beneficial outcome (NNTs) as the reciprocal of the absolute risk reduction (McQuay 1998). In the event of significant statistical heterogeneity we would consider using a random-effects model. For unwanted effects, the NNT becomes the number needed to treat for one additional harmful outcome (NNH), and is calculated in the same manner.

We planned to use the following terms to describe adverse outcomes in terms of harm or prevention of harm.

- When significantly fewer adverse outcomes occurred with tramadol with or without paracetamol than with control (placebo or active) we used the term number needed to treat to prevent one event (NNTp).

- When significantly more adverse outcomes occurred with tramadol with or without paracetamol compared with control (placebo or active) we used the term number needed to harm or cause one event (NNH).

We did not plan to use continuous data for the primary outcomes because it is inappropriate where there is an underlying skewed distribution, as is usually the case with analgesic response.

\section{Unit of analysis issues}

The unit of randomisation was the individual participant.

\section{Dealing with missing data}

We planned to use intention-to-treat (ITT) analysis: participants who were randomised, took the study medication, and gave a minimum of one post baseline assessment.

We did not use imputation methods for any missing data.

\section{Assessment of heterogeneity}

We planned to assess statistical heterogeneity using L'Abbé plots, a visual method for assessing differences in results of individual studies (L'Abbé 1987), and by use of the $I^{2}$ statistic. We anticipated that there could be an effect of differences between participant characteristics, environment (inpatient versus outpatient), and outcome measures. We planned to explore these with subgroup and sensitivity analyses where there were sufficient data.

\section{Assessment of reporting biases}

The aim of this review was to use dichotomous data of known utility (Moore 2010; Moore 2013). The review did not depend on what authors of the original studies chose to report or not.

We planned to undertake an assessment of publication bias if there were sufficient data for meta-analysis, using a method designed to detect the amount of unpublished data with a null effect required to make any result clinically irrelevant (usually taken to mean an NNT of 10 or higher) (Moore 2008).

\section{Data synthesis}

We planned to undertake a quantitative synthesis if there were sufficient data, and present the data in forest plots. We planned to analyse studies of tramadol alone separately from the tramadol plus paracetamol combination. In the event of substantial heterogeneity, we would not show the totals in the forest plots.

- We planned to undertake a meta-analysis only if we judged participants, interventions, comparisons and outcomes to be sufficiently similar to ensure an answer that is clinically meaningful.

- We planned to use RevMan 5 for meta-analysis (RevMan 2014), and Excel for NNTs and NNHs.

\section{Quality of the evidence}

We used the GRADE system to assess the quality of the evidence related to the key outcomes listed in Types of outcome measures, as appropriate (Appendix 5). Two review authors (PW, RAM) independently rated the quality of each outcome. We paid particular attention to inconsistency, where point estimates vary widely across studies or confidence intervals of studies show minimal or no overlap (Guyatt 2011), and potential for publication bias, based on the amount of unpublished data required to make the result clinically irrelevant (Moore 2008).

In addition, there may be circumstances where the overall rating for a particular outcome needs to be adjusted, as recommended by GRADE guidelines (Guyatt 2013a). For example, if there were so few data that the results were highly susceptible to the random play of chance, or if a study used LOCF imputation in circumstances where there were substantial differences in adverse event withdrawals, one would have no confidence in the result, and would need to downgrade the quality of the evidence by three levels, to very low quality. In circumstances where there were no data reported for an outcome, we have reported the level of evidence as very low quality (Guyatt 2013b).

There are also issues over both random chance effects with small amounts of data, and potential bias in small studies, especially in pain (Dechartres 2013; Dechartres 2014; Fanelli 2017; Moore 1998; Nguyen 2017; Nüesch 2010; Thorlund 2011). Cochrane Reviews have been criticised for perhaps over-emphasising results of underpowered studies or analyses (AlBalawi 2013; Turner 2013). However, it may be unethical to ignore potentially important information from small studies or to randomise more participants if a meta-analysis including small, existing studies provided conclusive evidence.

\section{'Summary of findings' table}

We included a 'Summary of findings' table as set out in the Pain, Palliative and Supportive Care Review Group author guide (PaPaS 2012), and recommended in Section 4.6.6 of the Cochrane Handbook for Systematic Reviews of Interventions (Higgins 2011). The table includes, where possible, the number of participants with pain reduction of $30 \%$ or $50 \%$ or greater, participants with pain no worse than mild, and PGIC of much improved or very much improved. We have also included serious adverse events, other 
adverse events, and withdrawals due to lack of efficacy or adverse events.

For the 'Summary of findings' table, we used the following descriptors for levels of evidence (EPOC 2015):

- High: This research provides a very good indication of the likely effect. The likelihood that the effect will be substantially different ${ }^{\dagger}$ is low.

- Moderate: This research provides a good indication of the likely effect. The likelihood that the effect will be substantially different ${ }^{\dagger}$ is moderate.

- Low: This research provides some indication of the likely effect. However, the likelihood that it will be substantially different ${ }^{\dagger}$ is high.

- Very low: This research does not provide a reliable indication of the likely effect. The likelihood that the effect will be substantially different ${ }^{\dagger}$ is very high.

† Substantially different: a large enough difference that it might affect a decision.

\section{Subgroup analysis and investigation of heterogeneity}

We planned to analyse separately the data for tramadol alone and tramadol plus paracetamol, and to carry out sensitivity analyses for duration of study, age of participants (younger than 18 years versus 18 years or older). This was not possible because there were insufficient data.

\section{RES U L T S}

\section{Description of studies}

\section{Results of the search}

Searches in November 2016 identified 606 potentially relevant records in CENTRAL, MEDLINE, Embase, and LILACS. We identified no additional studies as extended abstracts in clinical trial registries, neither with nor without results. After screening titles and abstracts, we obtained the full text of 16 articles (Figure 1). A restricted search in May 2017 found no additional studies. 
Figure 1. Study flow diagram.
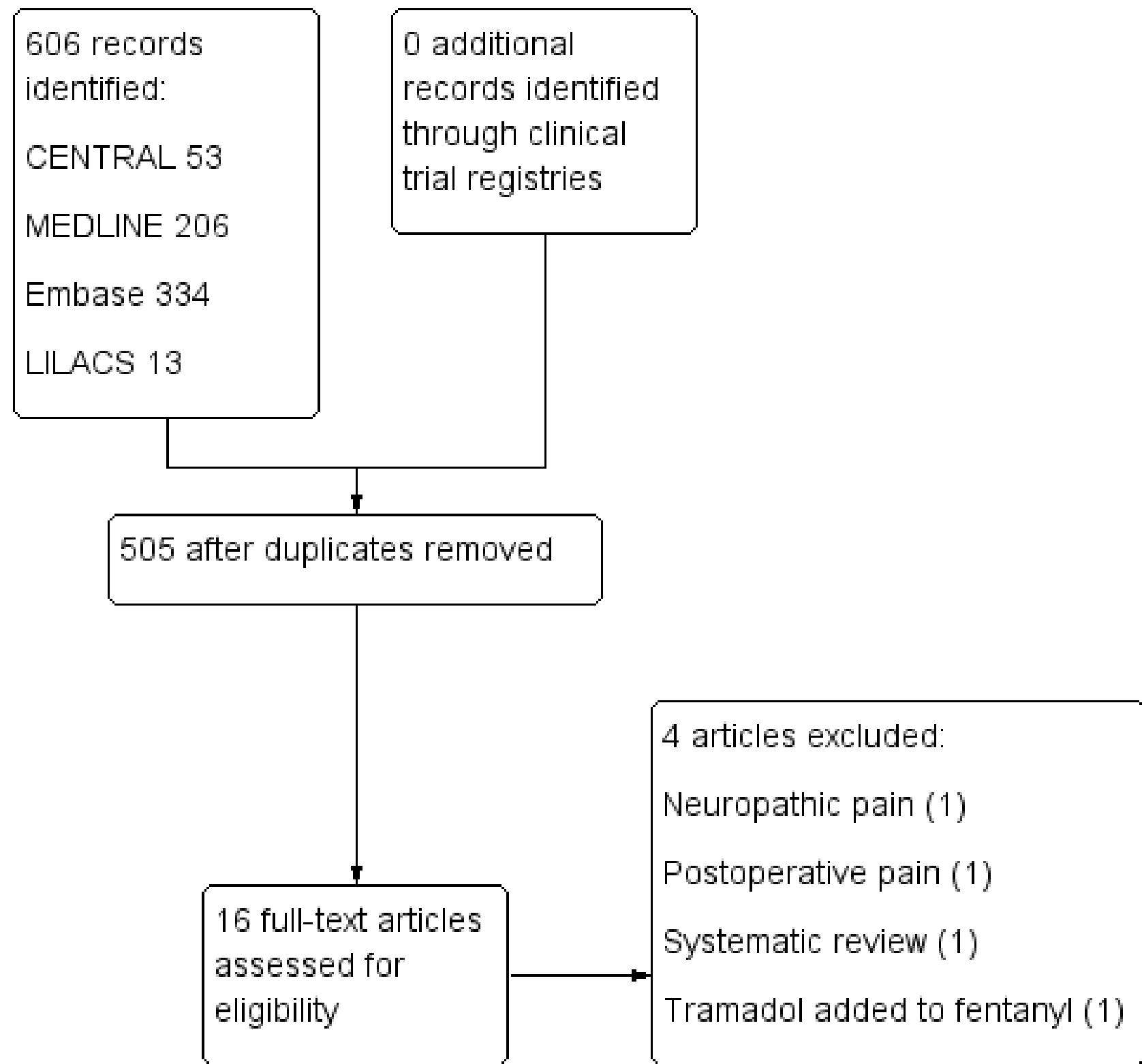

\section{Included studies}

We included 10 studies (12 reports) with 958 adult participants (Bandieri 2016; Bono 1997; Brema 1996; Leppert 2001; Leppert 2010; Luben 1994; Mercadante 2005; Rodriguez 2007; Wilder-
Smith 1994; Xu 2006). All the studies enrolled participants with chronic malignant tumour-related pain who were experiencing pain intensities described as moderate to severe, with most experiencing at least $4 / 10$ with current treatment. The mean ages were 59 to 70 years, with participants aged between 24 and 87 years. 
There were no studies in children. Study length ranged from one day (Xu 2006) to six months (Brema 1996).

\section{Titration phase}

Five studies titrated drugs to an effective dose (Bandieri 2016; Leppert 2001; Leppert 2010; Rodriguez 2007; Wilder-Smith 1994). One study adjusted doses within the treatment phases (Brema 1996). Mercadante 2005 used a basal dose but allowed additional drug for rescue.

\section{Cross-over}

Five studies used a cross-over design (Bono 1997; Leppert 2010; Mercadante 2005; Wilder-Smith 1994; Xu 2006). There was no standard approach. Mercadante 2005 followed a three-day regimen for each group, with no mention of washout between; WilderSmith 1994 used two four-day sessions with no washout; and Bono 1997 used one-week treatment periods, with a one-day washout between treatments. Leppert 2010 also used one-week treatment periods, but with no washout. Xu 2006 used single dose cross-overs, and the timing was not well explained.

\section{Doses of tramadol}

Doses ranged widely from $50 \mathrm{mg}$ as single dose (Xu 2006) to $600 \mathrm{mg}$ per day (Leppert 2001; Leppert 2010). Doses of $300 \mathrm{mg}$ per day to $400 \mathrm{mg}$ per day were most common.
Only one study used tramadol combined with paracetamol, and only four participants received this intervention (Bandieri 2016).

\section{Comparators}

One of the studies compared tramadol to placebo (Xu 2006).

Active comparators were:

- oral morphine (Bandieri 2016; Leppert 2001; Wilder-Smith 1994);

- buprenorphine (Bono 1997; Brema 1996);

- dihydrocodeine (DHC) (Leppert 2010);

- flupirtine (Luben 1994);

- hydrocodeine (Rodriguez 2007);

- paracetamol plus codeine (Rodriguez 2007);

- cobrotoxin plus tramadol plus ibuprofen (Xu 2006);

- rectal formulation of tramadol (Mercadante 2005).

\section{Excluded studies}

We excluded four potentially relevant studies after reading the full text (Arbaiza 2007; Marinangeli 2007; Tassinari 2011; Yavuz 2004). The reasons were that they studied neuropathic pain (Arbaiza 2007) or postoperative pain (Yavuz 2004), used tramadol plus fentanyl (Marinangeli 2007), or were a systematic review (Tassinari 2011).

\section{Risk of bias in included studies}

Risks of bias are shown in Figure 2 and Figure 3.

Figure 2. Risk of bias graph: review authors' judgements about each risk of bias item presented as percentages across all included studies.

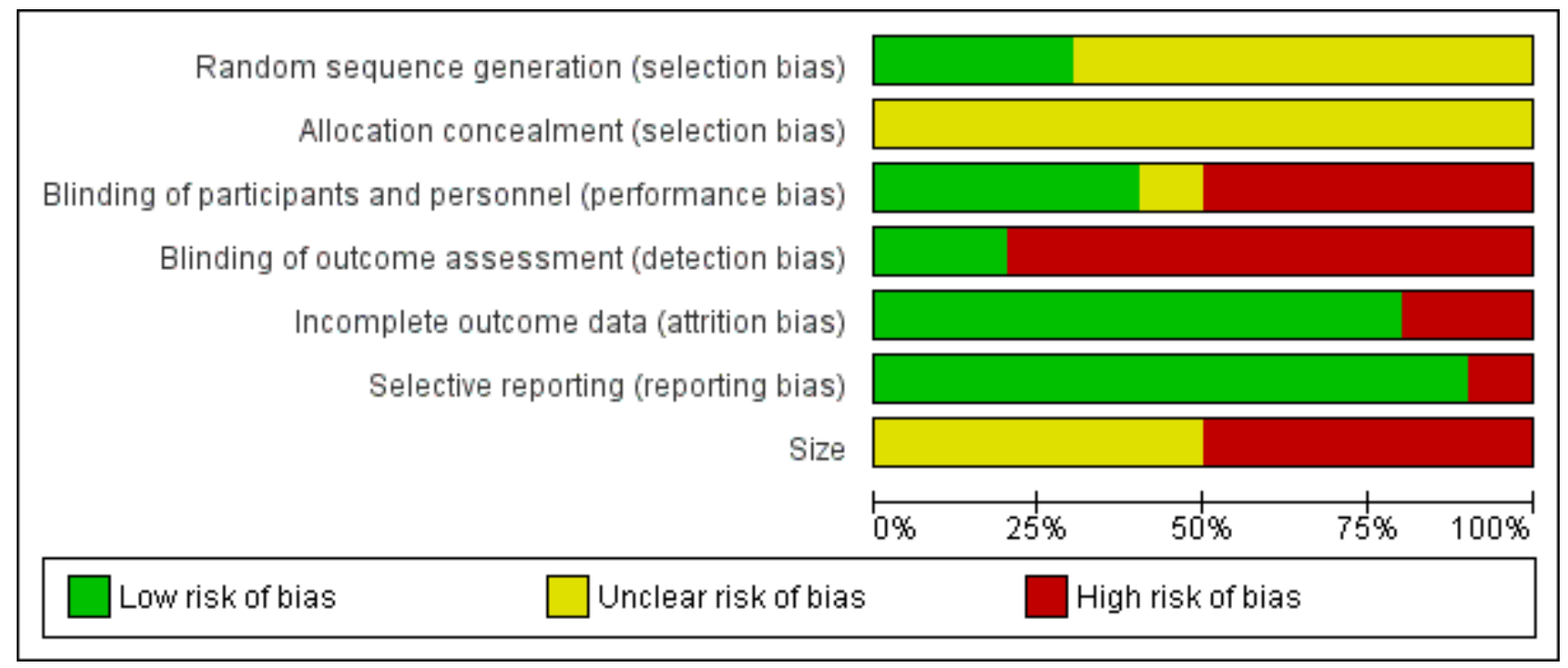


Figure 3. Risk of bias summary: review authors' judgements about each risk of bias item for each included study.

\begin{tabular}{|c|c|c|c|c|c|c|c|}
\hline & 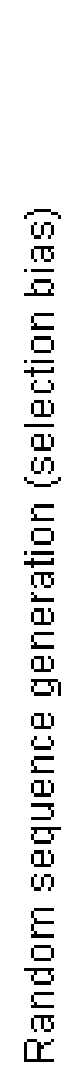 & 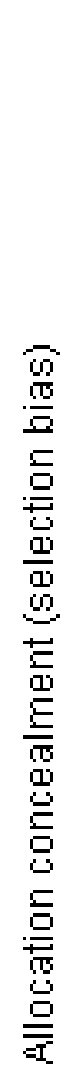 & 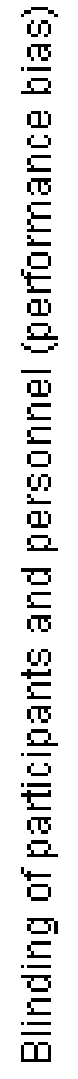 & 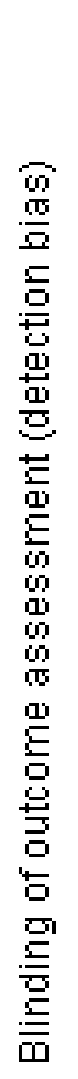 & 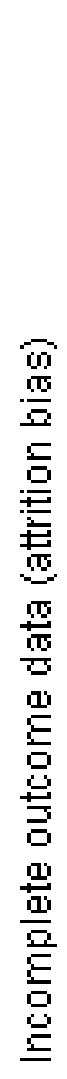 & 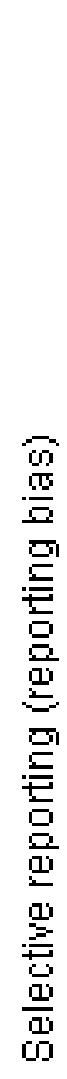 & $\frac{\mathbb{A}}{0}$ \\
\hline \multicolumn{8}{|l|}{ Bandieri 2016} \\
\hline Bono 1997 & $?$ & $?$ & & & & & $?$ \\
\hline Brema 1996 & $?$ & $?$ & & & & & $?$ \\
\hline Leppert 2001 & $?$ & $?$ & & & & & \\
\hline Leppert 2010 & $?$ & $?$ & & & & & \\
\hline Luben 1994 & $?$ & $?$ & + & & & & \\
\hline Mercadante 2005 & $?$ & $?$ & $A$ & & & & \\
\hline Rodriguez 2007 & + & $?$ & $?$ & & & & $?$ \\
\hline Wilder-Smith 1994 & $?$ & $?$ & + & + & 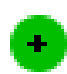 & & \\
\hline Xu 2006 & + & $?$ & + & + & + & + & $?$ \\
\hline
\end{tabular}




\section{Allocation}

All the studies stated that they were randomised, but only three reported adequate methods of sequence generation (Bandieri 2016; Rodriguez 2007; Xu 2006). No study described how allocation concealment was managed.

\section{Blinding}

Four studies adequately reported the methods used to maintain blinding of participants and study personnel (Luben 1994; Mercadante 2005; Wilder-Smith 1994; Xu 2006). Rodriguez 2007 reported that "drugs were packaged in identical containers" which we judged to be unclear. The remaining five studies were not blind and so were at high risk of bias.

Only two studies were judged at low risk of detection bias (WilderSmith 1994; Xu 2006); others were judged at high risk.

\section{Incomplete outcome data}

Two studies were judged at high risk for incomplete outcome reporting (Brema 1996; Mercadante 2005). There were no other problems identified.

\section{Selective reporting}

One study was judged at high risk for selective outcome reporting (Mercadante 2005). There were no other problems identified.

\section{Other potential sources of bias}

None of the included studies enrolled 200 or more participants per treatment arm, which we consider is the minimum required to give confidence in the results. Five studies enrolled fewer than 50 participants per treatment arm (Leppert 2001; Leppert 2010; Luben 1994; Mercadante 2005; Wilder-Smith 1994), which brings the validity of these studies into question. Three of the five studies had a cross-over design (Leppert 2010; Mercadante 2005; WilderSmith 1994).

\section{Effects of interventions}

See: Summary of findings for the main comparison Oral tramadol compared with oral morphine for cancer pain

Because of the small amount of information available for tramadol, alone or combined with paracetamol, for any outcome, and in any comparison, we judged the evidence to be very low quality throughout. In addition to small size, other issues influencing our judgement were widespread lack of blinding of outcome assessment, unclear methods of sequence generation and allocation concealment, and poor reporting of important outcomes. We have summarised the main results in Summary of findings for the main comparison.

\section{Pain}

\section{Tramadol versus morphine}

Three studies (300 participants) compared tramadol with morphine (Bandieri 2016; Leppert 2001; Wilder-Smith 1994). Bandieri 2016 regarded tramadol, tramadol plus paracetamol, and paracetamol plus codeine as a single weak opioid group. Of the 122 participants who received weak opioids, 23 received either tramadol alone (19 participants) or tramadol plus paracetamol (4four participants).
Therefore, results in this study need to be treated with caution and are not a reliable indication of the effects of tramadol.

\section{Number of participants with pain reduction of $\mathbf{3 0 \%}$ or greater from baseline}

In the weak opioid group as a whole, 55/117 (47\%) participants achieved a reduction in pain of at least $30 \%$ from baseline, compared with $91 / 110$ (82\%) participants in the morphine group (Bandieri 2016).

Leppert 2001 and Wilder-Smith 1994 did not report number of participants with pain reduction of $30 \%$ or greater from baseline.

\section{Number of participants with pain reduction of $50 \%$ or greater from baseline}

In the weak opioid group as a whole, 49/117 (42\%) participants achieved a reduction in pain of at least $50 \%$ from baseline, compared with $83 / 110$ (75\%) participants in the morphine group (Bandieri 2016).

Leppert 2001 and Wilder-Smith 1994 did not report number of participants with pain reduction of $50 \%$ or greater from baseline.

\section{Number of participants with pain no worse than mild}

We were unable to determine the number of participants with pain no worse than mild from any of the studies.

\section{Number of participants with PGIC of much improved or very much improved (or equivalent wording)}

We were unable to determine number of participants with PGIC of much improved or very much improved from any of the studies.

\section{Quality of life}

Only Leppert 2001 reported QoL outcomes. On the 35th day, emotional functioning was significantly better in the morphine group but participants in this group had more financial problems. There were no significant differences in other functioning.

\section{Use of rescue medication}

Bandieri 2016 reported that $41 / 117$ participants in the weak opioid group and $17 / 110$ in the morphine group were switched to another strong opioid; 33/117 required an increase in dose in the weak opioid group compared with $15 / 110$ in the morphine group.

Wilder-Smith 1994 reported that $8 / 20$ participants in the tramadol group requested additional medication, compared with $7 / 20$ in the morphine group.

Leppert 2001 did not report use of rescue medication.

\section{Participant satisfaction or preference}

Wilder-Smith 1994 reported that 3/20 participants preferred tramadol, 8/20 preferred morphine, and 9/20 expressed no preference.

Leppert 2001 reported that $16 / 20$ participants in both the tramadol and morphine groups preferred the sustained release versions. As this was a parallel group study, it was not possible for participants to express a preference between tramadol and morphine.

Bandieri 2016 did not report participant satisfaction or preference. 


\section{Tramadol versus buprenorphine}

Two studies (191 participants) compared tramadol with buprenorphine (Bono 1997; Brema 1996).

Number of participants with pain reduction of $30 \%$ or greater from baseline

We were unable to determine number of participants with pain reduction of $30 \%$ or greater from baseline from either of the studies.

\section{Number of participants with pain reduction of $50 \%$ or greater from} baseline

We were unable to determine number of participants with pain reduction of $50 \%$ or greater from baseline from either of the studies.

Number of participants with pain no worse than mild

At 14 days, 60/68 (88\%) participants receiving tramadol and 47/63 (75\%) participants receiving buprenorphine reported having no worse than mild pain (data derived from graph) (Brema 1996). Bono 1997 did not report number of participants with pain no worse than mild.

Number of participants with PGIC of much improved or very much improved (or equivalent wording)

We were unable to determine number of participants with PGIC of much improved or very much improved from either of the studies.

\section{Quality of life}

Bono 1997 reported the use of the Karnofsky performance indicator for QoL; there was little change in the index over the course of the study. Brema 1996 did not report on QoL.

\section{Use of rescue medication}

We were unable to determine use of rescue medication from either of the studies.

\section{Participant satisfaction or preference}

More participants favoured tramadol in the Bono 1997 study, but this was based on reports from both participants and investigators. Brema 1996 did not report participant preference.

\section{Tramadol versus dihydrocodeine (DHC)}

One study (40 participants) compared tramadol with dihydrocodeine (Leppert 2010).

\section{Number of participants with pain reduction of $30 \%$ or greater from} baseline

We were unable to determine number of participants with pain reduction of $30 \%$ or greater from baseline from this study.

\section{Number of participants with pain reduction of $50 \%$ or greater from} baseline

We were unable to determine number of participants with pain reduction of $50 \%$ or greater from baseline from this study.

Number of participants with pain no worse than mild

We were unable to determine number of participants with pain no worse than mild from this study.
Number of participants with PGIC of much improved or very much improved (or equivalent wording)

We were unable to determine number of participants with PGIC of much improved or very much improved from this study.

\section{Quality of life}

Participants reported better scores of emotional functioning in the tramadol group, and better global QoL scores and better cognitive functioning in the DHC group.

Use of rescue medication

Twelve participants in the tramadol group and eight in the DHC group required rescue medication.

\section{Participant satisfaction or preference}

Four participants preferred tramadol and 19 preferred DHC.

\section{Tramadol versus paracetamol plus codeine}

One study (177 participants), published in two reports, compared tramadol with paracetamol plus codeine (Rodriguez 2007).

Number of participants with pain reduction of $30 \%$ or greater from baseline

We were unable to determine number of participants with pain reduction of $30 \%$ or greater from baseline from this study.

\section{Number of participants with pain reduction of $50 \%$ or greater from} baseline

We were unable to determine number of participants with pain reduction of $50 \%$ or greater from baseline from this study.

Number of participants with pain no worse than mild

We were unable to determine number of participants with pain no worse than mild from this study.

Number of participants with PGIC of much improved or very much improved (or equivalent wording)

We were unable to determine number of participants with PGIC of much improved or very much improved from this study.

\section{Quality of life}

We were unable to determine QoL from this study.

\section{Use of rescue medication}

We were unable to determine use of rescue medication from this study.

\section{Participant satisfaction or preference}

We were unable to determine participant satisfaction or preference from this study.

\section{Oral tramadol versus rectal tramadol}

One study (60 participants) compared oral tramadol with rectal tramadol (Mercadante 2005).

Number of participants with pain reduction of $\mathbf{3 0} \%$ or greater from baseline

We were unable to determine number of participants with pain reduction of $30 \%$ or greater from baseline from this study. 
Number of participants with pain reduction of $50 \%$ or greater from baseline

We were unable to determine number of participants with pain reduction of $30 \%$ or greater from baseline from this study.

\section{Number of participants with pain no worse than mild}

We were unable to determine number of participants with pain no worse than mild from this study.

Number of participants with PGIC of much improved or very much improved (or equivalent wording)

We were unable to determine number of participants with PGIC of much improved or very much improved from this study.

\section{Quality of life}

We were unable to determine QoL from this study.

\section{Use of rescue medication}

There were no differences between oral and rectal tramadol in the number of rescue doses used.

\section{Participant satisfaction or preference}

The study reported that participants preferred the oral route, but no data were provided.

\section{Tramadol versus flupirtine}

One study (71 participants) compared tramadol with flupirtine (Luben 1994). The use of flupirtine, a non-opioid analgesic, is now severely restricted due to liver toxicity (EMA 2013). The only relevant outcome reported in this study was the use of rescue medication by $31 / 36$ in the tramadol group and 23/35 in the flupirtine group.

\section{Tramadol versus cobrotoxin}

One study (119 participants) compared tramadol with cobrotoxin plus tramadol plus ibuprofen (Xu 2006). This study had two parallel treatment arms in which participants took single doses of the cobrotoxin combination, placebo, and tramadol. One arm took the cobrotoxin combination first and the tramadol last, while the other took the tramadol first and the cobrotoxin combination last. If participants failed to get adequate pain relief from the first dose within one hour, they were instructed to take the next dose in the sequence (and presumably the third dose if no benefit). A period of one hour seems very short for tramadol to reach full effect, and an additional hour following placebo would not provide an adequate washout. For these reasons, we decided that it was impossible to use the results.

\section{Serious adverse events (including death)}

There was inconsistent reporting of serious adverse events across all comparisons.

Bandieri 2016 reported death in 1/122participants receiving weak opioid (not stated which opioid) and 2/118 receiving morphine. Leppert 2001 reported death in $2 / 20$ in the tramadol group and $1 / 20$ in the morphine group.

Brema 1996 reported withdrawal from the study due to disease progression or death in $27 / 68$ participants with tramadol group, and 22/63 with buprenorphine, but there was no indication of whether this was judged related to the interventions.
Leppert 2010 reported that there were no serious adverse events or deaths, and Luben 1994 reported that one participant withdrew with itchy erythema from flupirtine treatment, but it is unclear whether this was judged a serious adverse event. The remaining studies did not report on serious adverse events or deaths.

\section{Other adverse events, particularly reports of effects of treatment on somnolence, appetite, or thirst}

There was inconsistent reporting of other adverse events across all comparisons.

Only four studies provided data for participants experiencing any adverse event with tramadol (Brema 1996; Leppert 2001; WilderSmith 1994; Xu 2006). In total 29 participants out of 267 experienced an adverse event (11\%).

Four studies provided data on somnolence (Bono 1997; Brema 1996; Luben 1994; Rodriguez 2007). Somnolence was reported by 42 participants in a population of 220 (19\%). Effects on appetite and thirst were only reported in one study (Rodriguez 2007); 12/56 reported appetite related issues and $12 / 56$ reported a dry mouth.

\section{Attrition}

\section{Withdrawals due to lack of efficacy}

Six studies provided data on withdrawals due to lack of efficacy (Bono 1997; Brema 1996; Leppert 2001; Leppert 2010; Wilder-Smith 1994; Xu 2006). In total, 31/327 (9.5\%) participants withdrew due to lack of efficacy.

\section{Withdrawals due to adverse events}

Most studies reported withdrawals due to adverse events or poor tolerability; they were not reported in Rodriguez 2007, and were reported in a separate publication for Leppert 2010, in Polish. In the remaining studies, the rate of withdrawals varied greatly between studies, but there was no obvious difference between tramadol and any of the comparators used, except possibly for buprenorphine in one study (Bono 1997), but not the other (Brema 1996).

\section{DISCUSSION}

\section{Summary of main results}

No firm conclusions could be drawn for any outcome in any comparison.

There is very limited very low quality evidence that tramadol is not as effective an analgesic for cancer pain as morphine, but this is not surprising. We were able to determine the proportion of participants who achieved an outcome of 'no worse than mild pain' in only one study (Brema 1996; 60/68 participants with tramadol). In two studies, tramadol was similar to buprenorphine at the doses used. Comparisons with dihydrocodeine and codeine did not provide any useful data. In one small study, rectal tramadol was equivalent to oral tramadol. Comparisons with flupirtine are not relevant as flupirtine is no longer available. There was no useful information about tramadol combined with paracetamol.

\section{Overall completeness and applicability of evidence}

Given the widespread use of tramadol in palliative care, the amount of underpinning data is small. The most recent study compared tramadol with morphine (Bandieri 2016). Tramadol has a potential 
role on step 2 of the analgesic ladder, but good quality studies comparing tramadol with other step 2 drugs (e.g. codeine or dihydrocodeine) are missing, and there are no good data on those drugs either. Some authors have suggested eliminating the second step of the analgesic ladder, with weak opioids being replaced with low doses of oral morphine (Twycross 2014).

There were insufficient data to carry out any subgroup analyses. In particular, we were unable to investigate the influence of dose and titration regimen on either efficacy or tolerability. Included studies were underpowered to investigate serious adverse events.

We identified no studies in children.

\section{Quality of the evidence}

The evidence base identified by this review was small and limited in scope due to the small number of participants included in the different comparisons and the diversity of the study methodologies and outcome reporting. While not blinding treatments might be expected in older studies, two of the more recent studies were at high risk of bias due to a lack of blinding (Bandieri 2016; Leppert 2010).

Because of the small amount of information available for tramadol, alone or combined with paracetamol, for any outcome, and in any comparison, we judged the evidence to be very low quality throughout. Cochrane Reviews have been criticised for overemphasising results of underpowered studies or analyses (AlBalawi 2013; Turner 2013); small numbers of participants and events for important comparisons was a major issue in this review. As well as small size, other issues influencing our judgement were widespread lack of blinding of outcome assessment, unclear methods of sequence generation and allocation concealment, and poor reporting of important outcomes.

\section{Potential biases in the review process}

We are unaware of any potential biases in the review process.

\section{Agreements and disagreements with other studies or reviews}

We identified one published systematic review (Tassinari 2011). The authors stated, "Data supporting ...oral tramadol as an alternative to codeine plus paracetamol are insufficient to recommend its routine use in cancer patients with mild to moderate cancer pain." Our review, with 10 randomised studies, has more studies that the previous review, which also included abstracts, non-randomised studies, and different types of cancer pain, including neuropathic pain.

A number of other reviews have examined both the weak opioid codeine (Straube 2014), and strong opioids buprenorphine (Schmidt-Hansen 2015a), morphine (Wiffen 2016), oxycodone (Schmidt-Hansen 2015b), and tapentadol (Wiffen 2015). The amount of evidence in some of these reviews was also limited. For example, the review of codeine, with or without paracetamol, included 15 studies and 751 participants, but was unable to provide any good information on efficacy or adverse events (Straube 2014). The review on oral morphine had the largest amount of useable data, reporting that in 17 studies, 'no worse than mild pain' was achieved by $362 / 377$ (96\%) participants, and an outcome equivalent to treatment success in $400 / 638$ (63\%) participants (Wiffen 2016).

\section{AUTHORS' CONCLUSIONS}

\section{Implications for practice}

\section{For people with cancer pain}

There is limited very low quality evidence from randomised controlled trials that tramadol produces pain relief in some adults with pain due to cancer. The place of tramadol in managing cancer pain is unclear.

\section{For clinicians managing cancer pain}

There are few options to treat mild to moderate cancer pain before moving to strong opioids such as morphine. There is no clear evidence to support the use of tramadol in mild to moderate pain, or severe pain.

\section{For policy makers}

Tramadol may have a role if other opioids are not tolerated, providing the issues of dose titration and possible severe adverse effects are considered. There is no information for the use of tramadol in paediatrics.

\section{For organisations or bodies making decisions about funding treatment options}

Tramadol may have a place on formularies but its role as an analgesic for cancer pain is unclear.

\section{Implications for research}

\section{General implications}

Research in this patient population is challenging, and a large trial of high quality that minimises bias has not been conducted. Furthermore, there are few options for step 2 on the WHO analgesic ladder.

\section{Implications for study design}

Key issues for study design are now well understood, yet we continue to see published studies that do not adequately describe randomisation and allocation concealment. Blinding of studies is still not routinely undertaken, and numbers of participants remain low (Bandieri 2016). These issues should be of concern to research ethics committees.

\section{Implications for measurement and outcomes}

As the distribution of response to analgesics is often bimodal, we strongly recommend the collection of dichotomous data in preference to mean pain scores. Data should be available to allow the estimation of the proportion of participants who achieve no worse than mild pain, defined as below $30 \mathrm{~mm}$ on a $100-\mathrm{mm}$ visual analogue scale (VAS) pain intensity scale. Adverse events should always be reported but we advocate specific reporting of events affecting appetite, thirst, consciousness, and somnolence - issues that seriously affect people's lives in the last stages of illness.

Other considerations for future study design include: 
- use of standard and comparable pain intensity scores, which would allow closer comparison between different studies and potentially facilitate meta-analysis;

- inclusion of only participant-reported pain and other data;

- larger numbers of participants in studies where differentiation by condition has been attempted, to answer the question as to whether tramadol is particularly valuable in cancer-related bone or neuropathic pain;

- participant satisfaction and quality of life appraisal.

\section{ACKN OWLEDGEMENTS}

We are grateful to Prof Patrice Forget of the Université Catholique de Louvain, Belgium for help with data extraction of a French language paper. Sebastian Straube helped with data extraction of a German language paper and Celia Almeida helped with a Spanish language paper.

Cochrane Review Group funding acknowledgement: this project was supported by the National Institute for Health Research, via Cochrane Infrastructure funding to the Cochrane Pain, Palliative and Supportive Care Review Group (PaPaS). The views and opinions expressed therein are those of the authors and do not necessarily reflect those of the Systematic Reviews Programme, NIHR, NHS or the Department of Health.

Institutional support was provided by the Oxford Pain Relief Trust. 


\section{RE F E R E N C E S}

\section{References to studies included in this review}

Bandieri 2016 \{published data only\}

Bandieri E, Romero M, Ripamonti Cl, Artioli F, Sichetti D, Fanizza C, et al. Randomized trial of low-dose morphine versus weak opioids in moderate cancer pain. Journal of Clinical Oncology 2016;34(5):436-42. [DOI: 10.1200/JCO.2015.61.0733]

\section{Bono 1997 \{published data only\}}

Bono AV, Cuffari S. Effectiveness and tolerance of tramadol in cancer pain. A comparative study with respect to buprenorphine [Efficacite et tolerance du tramadol dans les douleurs neoplasiques. Etude comparative par rapport a la buprenorphine]. Drugs 1997;53 (Suppl 2):40-9. [PUBMED: 9190324]

\section{Brema 1996 \{published data only\}}

Brema F, Pastorino G, Martini MC, Gottlieb A, Luzzani M, Libretti $A$, et al. Oral tramadol and buprenorphine in tumour pain. An Italian multicentre trial. International Journal of Clinical Pharmacology Research 1996;16(4-5):109-16. [PUBMED: 9172009]

\section{Leppert 2001 \{published data only\}}

Leppert W. Analgesic efficacy and side effects of oral tramadol and morphine administered orally in the treatment of pain. Nowotwory 2001;51:257-66.

\section{Leppert 2010 \{published data only\}}

Leppert W, Majkowicz M. The impact of tramadol and dihydrocodeine treatment on quality of life of patients with cancer pain. International Journal of Clinical Practice 2010;64(12):1681-7. [DOI: 10.1111/j.1742-1241.2010.02422.x]

\section{Luben 1994 \{published data only\}}

Luben V, Muller H, Lobisch M, Worz R. Treatment of tumor pain with flupirtine. Results of a double-blind study versus tramadol. Fortschritte der Medizin 1994;112(19):282-6. [PUBMED: 7927099]

\section{Mercadante 2005 \{published data only\}}

Mercadante S, Arcuri E, Fusco F, Tirelli W, Villari P, Bussolino C, et al. Randomized double-blind, double-dummy crossover clinical trial of oral tramadol versus rectal tramadol administration in opioid-naive cancer patients with pain. Supportive Care in Cancer 2005;13(9):702-7. [DOI: 10.1007/ s00520-004-0760-9]

\section{Rodriguez 2007 \{published data only\}}

* Rodriguez RF, Bravo LE, Castro F, Montoya O, Castillo JM, Castillo MP, et al. Incidence of weak opioids adverse events in the management of cancer pain: a double-blind comparative trial. Journal of Palliative Medicine 2007;10(1):56-60. [DOI: 10.1089/jpm.2006.0117]

Rodriguez RF, Castillo JM, Castillo MP, Montoya O, Daza P, Rodriguez MF, et al. Hydrocodone/acetaminophen and tramadol chlorhydrate combination tablets for the management of chronic cancer pain: a double-blind comparative trial. [Erratum appears in Clinical Journal of Pain
2008;24(7):649]. Clinical Journal of Pain 2008;24(1):1-4. [DOI: 10.1097/AJP.0b013e318156ca4d]

Wilder-Smith 1994 \{published data only\}

Wilder-Smith CH, Schimke J, Osterwalder B, Senn HJ. Oral tramadol, a mu-opioid agonist and monoamine reuptakeblocker, and morphine for strong cancer-related pain. Annals of Oncology 1994;5(2):141-6. [PUBMED: 8186157]

\section{Xu 2006 \{published data only\}}

Xu JM, Song ST, Feng FY, Huang FL, Yang Y, Xie GR, et al. Cobrotoxin-containing analgesic compound to treat chronic moderate to severe cancer pain: results from a randomized, double-blind, cross-over study and from an open-label study. Oncology Reports 2006;16(5):1077-84. [DOI: 10.3892/ or.16.5.1077]

\section{References to studies excluded from this review}

Arbaiza 2007 \{published data only\}

Arbaiza D, Vidal O. Tramadol in the treatment of neuropathic cancer pain: a double-blind, placebo-controlled study. Clinical Drug Investigation 2007;27(1):75-83. [DOI: 10.2165/00044011-200727010-00007]

\section{Marinangeli 2007 \{published data only\}}

Marinangeli F, Ciccozzi A, Aloisio L, Colangeli A, Paladini A, Bajocco C, et al. Improved cancer pain treatment using combined fentanyl-TTS and tramadol. Pain Practice 2007;7(4):307-12. [DOI: 10.1111/j.1533-2500.2007.00155.x]

\section{Tassinari 2011 \{published data only\}}

Tassinari D, Drudi F, Rosati M, Tombesi P, Sartori S, Maltoni M. The second step of the analgesic ladder and oral tramadol in the treatment of mild to moderate cancer pain: a systematic review. Palliative Medicine 2011;25(5):410-23. [DOI: 10.1177/0269216311405090]

\section{Yavuz 2004 \{published data only\}}

Yavuz L, Eroglu F, Ozsoy M. The efficacy of intravenous versus epidural tramadol with patient-controlled analgesia (PCA) in gynecologic cancer pain. European Journal of Gynaecological Oncology 2004;25(2):215-8. [PUBMED: 15032285]

\section{Additional references}

\section{AlBalawi 2013}

AlBalawi Z, McAlister FA, Thorlund K, Wong M, Wetterslev J. Random error in cardiovascular meta-analyses: how common are false positive and false negative results?. International Journal of Cardiology 2013;168(2):1102-7. [DOI: 10.1016/ j.ijcard.2012.11.048]

\section{Bao 2016}

Bao YJ, Hou W, Kong XY, Yang L, Xia J, Hua BJ, et al. Hydromorphone for cancer pain. Cochrane Database of Systematic Reviews 2016, Issue 10. [DOI: 10.1002/14651858.CD011108.pub2] 


\section{Beakley 2015}

Beakley BD, Kaye AM, Kaye AD. Tramadol, pharmacology, side effects, and serotonin syndrome: a review. Pain Physician 2015;18(4):395-400. [PUBMED: 26218943]

\section{Bozkurt 2005}

Bozkurt P. Use of tramadol in children. Paediatric Anaesthesia 2005;15(12):1041-7. [DOI: 10.1111/j.1460-9592.2005.01738.x]

\section{Breivik 2009}

Breivik H, Cherny N, Collett B, de Conno F, Filbet M, Foubert AJ, et al. Cancer-related pain: a pan-European survey of prevalence, treatment, and patient attitudes. Annals of Oncology 2009;20(8):1420-33. [DOI: 10.1093/annonc/mdp001]

\section{Cancer Research UK 2016}

Cancer Research UK. Cancer statistics for the UK. www.cancerresearchuk.org/health-professional/cancerstatistics (accessed 21 November 2016).

\section{Cepeda 2006}

Cepeda MS, Camargo F, Zea C, Velencia L. Tramadol for osteoarthritis. Cochrane Database of Systematic Reviews 2006, Issue 3. [DOI: 10.1002/14651858.CD005522.pub2]

\section{Dechartres 2013}

Dechartres A, Trinquart L, Boutron I, Ravaud P. Influence of trial sample size on treatment effect estimates: metaepidemiological study. BMJ 2013;346:f2304. [DOI: 10.1136/ bmj.f2304]

\section{Dechartres 2014}

Dechartres A, Altman DG, Trinquart L, Boutron I, Ravaud P. Association between analytic strategy and estimates of treatment outcomes in meta-analyses. JAMA 2014;312:623-30. [DOI: 10.1001/jama.2014.8166]

\section{Deng 2012}

Deng D, Fu L, Zhao YX, Wu X, Zhang G, Liang C, et al. The relationship between cancer pain and quality of life in patients newly admitted to Wuhan Hospice Center of China. American Journal of Hospital Palliative Care 2012;29(1):53-9. [DOI: 10.1177/1049909111418636]

\section{Dreidi 2016}

Dreidi MM, Hamdan-Mansour AM. Pain, sleep disturbance, and quality of life among Palestinian patients diagnosed with cancer. Journal of Cancer Education 2016;31(4):796-803. [DOI: 10.1007/s13187-015-0946-5]

\section{Dworkin 2008}

Dworkin RH, Turk DC, Wyrwich KW, Beaton D, Cleeland CS, Farrar JT, et al. Interpreting the clinical importance of treatment outcomes in chronic pain clinical trials: IMMPACT recommendations. Journal of Pain 2008;9(2):105-21. [DOI: 10.1016/j.jpain.2007.09.005]

\section{Edwards 2002}

Edwards JE, McQuay HJ, Moore RA. Combination analgesic efficacy: individual patient data meta-analysis of single-dose oral tramadol plus acetaminophen in acute postoperative pain.
Journal of Pain and Symptom Management 2002;23(2):121-30. [DOI: 10.1016/S0885-3924(01)00404-3]

\section{EMA 2013}

European Medicines Agency. Flupirtine-containing medicines. www.ema.europa.eu/ema/index.jsp?curl=pages/medicines/ human/referrals/Flupirtine-containing_medicines/human_ referral_prac_000019.jsp (accessed 24 January 2017).

\section{EPOC 2015}

Effective Practice, Organisation of Care (EPOC). 23. Worksheets for preparing a Summary of Findings using GRADE. Resources for review authors, 2015. epoc.cochrane.org/epoc-specificresources-review-authors (accessed 30 November 2016).

\section{Fanelli 2017}

Fanelli D, Costas R, loannidis JP. Meta-assessment of bias in science. Proceedings of the National Academy of Sciences of the United States of America 2017;114(14):3714-9. [DOI: 10.1073/ pnas.1618569114]

\section{Gan 2007}

Gan SH, Ismail R, Wan Adnan WA, Zulmi W. Impact of CYP2D6 genetic polymorphism on tramadol pharmacokinetics and pharmacodynamics. Molecular Diagnosis and Therapy 2007;11(3):171-81. [DOI: 10.1007/BF03256239]

\section{Grond 2004}

Grond S, Sablotzki A. Clinical pharmacology of tramadol. Clinical Pharmacokinetics 2004;43(13):879-932. [DOI: 10.2165/00003088-200443130-00004]

\section{Guyatt 2011}

Guyatt GH, Oxman AD, Kunz R, Woodcock J, Brozek J, Helfand M, et al. GRADE guidelines: 7 . Rating the quality of evidence - inconsistency. Journal of Clinical Epidemiology 2011;64(12):1294-302. [DOI: 10.1016/j.jclinepi.2011.03.017]

\section{Guyatt 2013a}

Guyatt G, Oxman AD, Sultan S, Brozek J, Glasziou P, AlonsoCoello P, et al. GRADE guidelines: 11 . Making an overall rating of confidence in effect estimates for a single outcome and for all outcomes. Journal of Clinical Epidemiology 2013;66:151-7. [DOI: 10.1016/j.jclinepi.2012.01.006]

\section{Guyatt 2013b}

Guyatt GH, Oxman AD, Santesso N, Helfand M, Vist G, Kunz R, et al. GRADE guidelines: 12 . Preparing summary of findings tables - binary outcomes. Journal of Clinical Epidemiology 2013;66:158-72. [DOI: 10.1016/j.jclinepi.2012.01.012]

\section{Hadley 2013}

Hadley G, Derry S, Moore RA, Wiffen PJ. Transdermal fentanyl for cancer pain. Cochrane Database of Systematic Reviews 2013, Issue 10. [DOI: 10.1002/14651858.CD010270.pub2]

\section{Higgins 2011}

Higgins JP, Green S, editor(s). Cochrane Handbook for Systematic Reviews of Interventions Version 5.1.0 (updated March 2011). The Cochrane Collaboration, 2011. Available from handbook.cochrane.org. 


\section{Hollingshead 2006}

Hollingshead J, Dühmke RM, Cornblath DR. Tramadol for neuropathic pain. Cochrane Database of Systematic Reviews 2006, Issue 3. [DOI: 10.1002/14651858.CD003726.pub3]

\section{IARC 2012}

International Agency for Research on Cancer. GLOBOCAN 2012: estimated cancer incidence, mortality and prevalence worldwide in 2012. globocan.iarc.fr/Pages/ fact_sheets_cancer.aspx (accessed 21 November 2016).

\section{L'Abbé 1987}

L'Abbé KA, Detsky AS, O'Rourke K. Meta-analysis in clinical research. Annals of Internal Medicine 1987;107(2):224-33. [DOI: 10.7326/0003-4819-107-2-224]

\section{Lintz 1998}

Lintz W, Barth H, Osterloh G, Schmidt-Bothelt E. Pharmacokinetics of tramadol and bioavailability of enteral tramadol formulations. 3rd Communication: suppositories. Arzneimittel-Forschung 1998;48(9):889-99. [PUBMED: 9793614]

\section{Martindale 2016}

Brayfield A, editor. Tramadol hydrochloride. Martindale - the complete drug reference (available at medicinescomplete.com) (accessed 21 November 2016). 8th Edition. London: Pharmaceutical Press, 2016.

\section{McQuay 1998}

McQuay H, Moore A. An Evidence-based Resource for Pain Relief. Oxford: Oxford University Press, 1998. [ISBN: 0-19-263048-2]

\section{Mikan 2016}

Mikan F, Wada M, Yamada M, Takahashi A, Onishi H, Ishida M, et al. The association between pain and quality of life for patients with cancer in an outpatient clinic, an inpatient oncology ward, and inpatient palliative care units. American Journal of Hospital Palliative Care 2016;33(8):782-90. [DOI: 10.1177/1049909116630266]

\section{Minami 2015}

Minami K, Ogata J, Uezono Y. What is the main mechanism of tramadol?. Naunyn-Schmiedebergs Archiv fur Pharmakologie 2015;388:999-1007. [DOI: 10.1007/s00210-015-1167-5]

\section{Moher 2009}

Moher D, Liberati A, Tetzlaff J, Altman DG, the PRISMA Group. Preferred reporting items for systematic reviews and meta-analyses: the PRISMA statement. PLoS Medicine 2009;6(7):e1000097. [DOI: 10.1371/journal.pmed.1000097]

\section{Moore 1997}

Moore RA, McQuay HJ. Single-patient data meta-analysis of 3453 postoperative patients: oral tramadol versus placebo, codeine and combination analgesics. Pain 1997;69(3):287-94. [DOI: 10.1016/S0304-3959(96)03291-5]

\section{Moore 1998}

Moore RA, Gavaghan D, Tramèr MR, Collins SL, McQuay HJ. Size is everything - large amounts of information are needed to overcome random effects in estimating direction and magnitude of treatment effects. Pain 1998;78(3):209-16. [DOI: 10.1016/S0304-3959(98)00140-7]

\section{Moore 2008}

Moore RA, Barden J, Derry S, McQuay HJ. Managing potential publication bias. In: McQuay HJ, Kalso E, Moore RA editor(s). Systematic Reviews in Pain Research: Methodology Refined. Seattle: IASP Press, 2008:15-24. [ISBN: 978-0-931092-69-5]

\section{Moore 2010}

Moore RA, Moore OA, Derry S, Peloso PM, Gammaitoni AR, Wang H. Responder analysis for pain relief and numbers needed to treat in a meta-analysis of etoricoxib osteoarthritis trials: bridging a gap between clinical trials and clinical practice. Annals of the Rheumatic Diseases 2010;69(2):374-9. [DOI: 10.1136/ard.2009.107805]

\section{Moore 2013}

Moore RA, Straube S, Aldington D. Pain measures and cut-offs - 'no worse than mild pain' as a simple, universal outcome. Anaesthesia 2013;68(4):400-12. [DOI: 10.1111/anae.12148]

\section{Nguyen 2017}

Nguyen TL, Collins GS, Lamy A, Devereaux PJ, Daurès JP, Landais $P$, et al. Simple randomization did not protect against bias in smaller trials. Journal of Clinical Epidemiology 2017;S0895-4356(16):30344-4. [DOI: 10.1016/ j.jclinepi.2017.02.010]

\section{NICE 2016}

National Institute for Health and Care Excellence. Palliative cancer care - pain, 2016. cks.nice.org.uk/palliative-cancer-carepain (accessed 2 February 2017).

\section{Nicholson 2017}

Nicholson AB, Watson GR, Derry S, Wiffen PJ. Methadone for cancer pain. Cochrane Database of Systematic Reviews 2017, Issue 2. [DOI: 10.1002/14651858.CD003971.pub4]

\section{Nüesch 2010}

Nüesch E, Trelle S, Reichenbach S, Rutjes AW, Tschannen B, Altman DG, et al. Small study effects in meta-analyses of osteoarthritis trials: meta-epidemiological study. BMJ 2010;341:c3515. [DOI: 10.1136/bmj.c3515]

\section{PaPaS 2012}

Cochrane Pain, Palliative and Supportive Care Group. PaPaS author and referee guidance. papas.cochrane.org/papasdocuments (accessed 21 November 2016).

\section{Pedersen 2005}

Pedersen RS, Damkier P, Brosen K. Tramadol as a new probe for cytochrome P450 2D6 phenotyping: a population study. Clinical Pharmacology and Therapeutics 2005;77(6):458-67. [DOI: 10.1016/j.clpt.2005.01.014]

\section{Portenoy 1999}

Portenoy RK, Lesage P. Management of cancer pain. Lancet 1999;353(9165):1695-700. [DOI: 10.1016/ S0140-6736(99)01310-0] 


\section{Prommer 2015}

Prommer EE. Pharmacological management of cancer-related pain. Cancer Control 2015;22(4):412-25. [PUBMED: 26678968]

\section{Radbruch 2013}

Radbruch L, Glaeske G, Grond S, Münchberg F, Scherbaum N, Storz E, et al. Topical review on the abuse and misuse potential of tramadol and tilidine in Germany. Substance Abuse 2013;34(3):313-20. [DOI: 10.1080/08897077.2012.735216]

\section{Reeves 2008}

Reeves RR, Burke RS. Tramadol: basic pharmacology and emerging concepts. Drugs of Today (Barcelona, Spain : 1998) 2008;44(11):827-36. [DOI: 10.1358/dot.2008.44.11.1289441]

\section{RevMan 2014 [Computer program]}

The Nordic Cochrane Centre, The Cochrane Collaboration. Review Manager. Version 5.3. Copenhagen: The Nordic Cochrane Centre, The Cochrane Collaboration, 2014.

\section{Schmidt-Hansen 2015a}

Schmidt-Hansen M, Bromham N, Taubert M, Arnold S, Hilgart JS. Buprenorphine for treating cancer pain. Cochrane Database of Systematic Reviews 2015, Issue 3. [DOI: 10.1002/14651858.CD009596.pub4]

\section{Schmidt-Hansen 2015b}

Schmidt-Hansen M, Bennett MI, Arnold S, Bromham N, Hilgart JS. Oxycodone for cancer-related pain. Cochrane Database of Systematic Reviews 2015, Issue 2. [DOI: 10.1002/14651858.CD003870.pub5]

\section{Scott 2000}

Scott LJ, Perry CM. Tramadol: a review of its use in perioperative pain. Drugs 2000;60(1):139-76. [DOI: $10.2165 / 00003495-200060010-00008]$

\section{Straube 2014}

Straube C, Derry S, Jackson KC, Wiffen PJ, Bell RF, Strassels S, et al. Codeine, alone and with paracetamol (acetaminophen), for cancer pain. Cochrane Database of Systematic Reviews 2014, Issue 9. [DOI: 10.1002/14651858.CD006601.pub4]

\section{Thorlund 2011}

Thorlund K, Imberger G, Walsh M, Chu R, Gluud C, Wetterslev J, et al. The number of patients and events required to limit the risk of overestimation of intervention effects in meta-analysis - a simulation study. PLoS One 2011;6(10):e25491. [DOI: 10.1371/ journal.pone.0025491]

\section{Turner 2013}

Turner RM, Bird SM, Higgins JP. The impact of study size on meta-analyses: examination of underpowered studies in Cochrane reviews. PLoS One 2013;8(3):e59202. [DOI: 10.1371/ journal.pone.0059202]

\section{Twycross 2014}

Twycross R, Wilcock A, Howard P. Palliative Care Formulary. Nottingham: Palliativedrugs.com Ltd, 2014.

\section{van den Beuken-van Everdingen 2016}

van den Beuken-van Everdingen $\mathrm{MH}$, Hochstenbach LM, Joosten EA, Tjan-HeijnenVC, Janssen DJ. Update on prevalence of pain in patients with cancer: systematic review and meta-analysis. Journal of Pain and Symptom Management 2016;51:1070-90. [DOI: 10.1016/j.jpainsymman.2015.12.340]

\section{WHO 2016}

World Health Organization. WHO analgesic ladder. www.who.int/cancer/palliative/painladder/en/ (accessed 21 November 2016).

\section{Wiffen 2013}

Wiffen PJ, Wee B, Moore RA. Oral morphine for cancer pain. Cochrane Database of Systematic Reviews 2013, Issue 7. [DOI: 10.1002/14651858.CD003868.pub3]

\section{Wiffen 2014}

Wiffen PJ, Derry S, Moore RA. Impact of morphine, fentanyl, oxycodone or codeine on patient consciousness, appetite and thirst when used to treat cancer pain. Cochrane Database of Systematic Reviews 2014, Issue 5. [DOI: 10.1002/14651858.CD011056.pub2]

\section{Wiffen 2015}

Wiffen PJ, Derry S, Naessens K, Bell RF. Oral tapentadol for cancer pain. Cochrane Database of Systematic Reviews 2015, Issue 9. [DOI: 10.1002/14651858.CD011460.pub2]

\section{Wiffen 2016}

Wiffen PJ, Wee B, Moore RA. Oral morphine for cancer pain. Cochrane Database of Systematic Reviews 2016, Issue 4. [DOI: 10.1002/14651858.CD003868.pub4]

* Indicates the major publication for the study

\section{CHARACTERISTICS OF STUDIES}

Characteristics of included studies [ordered by study ID]

Bandieri 2016

Methods $\quad$ Multicentre, randomised, open-label, parallel group.
Duration: 28 days.

Duration: 28 days. 
Bandieri 2016 (Continued)

Participants

240 participants. Moderate cancer pain (mostly visceral and somatic) scoring 4/10 to $6 / 10$ on NRS, opioid naive. Median age 68 years. Male 56\%.

Interventions

Weak opioid: tramadol alone up to $400 \mathrm{mg} /$ day, or tramadol + paracetamol, or paracetamol $4000 \mathrm{mg}+$ codeine up to $180 \mathrm{mg}$ daily, $\mathrm{n}=122$ (tramadol alone $=19$, tramadol + paracetamol $=4$ ).

Morphine up to $30 \mathrm{mg} /$ day modified release following titration, $\mathrm{n}=118$.

\section{Notes}

\section{Risk of bias}

\begin{tabular}{lll}
\hline Bias & Authors' judgement & Support for judgement \\
\hline $\begin{array}{l}\text { Random sequence genera- } \\
\text { tion (selection bias) }\end{array}$ & Low risk & "Centralized using a computer-generated procedure." \\
\hline $\begin{array}{l}\text { Allocation concealment } \\
\text { (selection bias) }\end{array}$ & Unclear risk & Method of allocation not reported. \\
\hline $\begin{array}{l}\text { Blinding of participants } \\
\text { and personnel (perfor- } \\
\text { mance bias) }\end{array}$ & High risk & Open-label study. \\
All outcomes & \\
\hline $\begin{array}{l}\text { Blinding of outcome as- } \\
\text { sessment (detection bias) }\end{array}$ & High risk & Not stated. \\
All outcomes & & \\
\hline $\begin{array}{l}\text { Incomplete outcome data } \\
\text { (attrition bias) } \\
\text { All outcomes }\end{array}$ & Low risk & No problems identified. \\
\hline $\begin{array}{l}\text { Selective reporting (re- } \\
\text { porting bias) }\end{array}$ & Low risk & No problems identified. \\
\hline \begin{tabular}{l} 
Size \\
\hline
\end{tabular} & Unclear risk & \\
\hline
\end{tabular}

Bono 1997

$\begin{array}{ll}\text { Methods } & \text { Randomised, open-label, cross-over study. } \\ & \text { Duration } 29 \text { days: } 1 \text { week washout, } 1 \text { week } 1 \text { st intervention, } 1 \text { day washout, } 1 \text { week 2nd intervention. }\end{array}$


Bono 1997 (Continued)

$\begin{array}{ll}\text { Interventions } & \text { Tramadol oral } 100 \mathrm{mg} 3 \text { times daily. } \\ & \text { Buprenorphine } 0.2 \mathrm{mg} 3 \text { times daily. }\end{array}$

Outcomes $\quad$ PI: 100-mm VAS during first 3 hours of study and at end of each treatment period.

QoL.

Use of rescue medication.

Participant satisfaction.

Adverse events.

Withdrawals.

\section{Notes}

\section{Risk of bias}

\begin{tabular}{|c|c|c|}
\hline Bias & Authors' judgement & Support for judgement \\
\hline $\begin{array}{l}\text { Random sequence genera- } \\
\text { tion (selection bias) }\end{array}$ & Unclear risk & Stated to be randomised, method of sequence generation not reported. \\
\hline $\begin{array}{l}\text { Allocation concealment } \\
\text { (selection bias) }\end{array}$ & Unclear risk & Method of allocation not reported. \\
\hline $\begin{array}{l}\text { Blinding of participants } \\
\text { and personnel (perfor- } \\
\text { mance bias) } \\
\text { All outcomes }\end{array}$ & High risk & Open-label study. \\
\hline $\begin{array}{l}\text { Blinding of outcome as- } \\
\text { sessment (detection bias) } \\
\text { All outcomes }\end{array}$ & High risk & Not stated. \\
\hline $\begin{array}{l}\text { Incomplete outcome data } \\
\text { (attrition bias) } \\
\text { All outcomes }\end{array}$ & Low risk & No problems identified. \\
\hline $\begin{array}{l}\text { Selective reporting (re- } \\
\text { porting bias) }\end{array}$ & Low risk & No problems identified. \\
\hline Size & Unclear risk & 60 participants in cross-over. \\
\hline
\end{tabular}

\section{Brema 1996}

\begin{tabular}{ll}
\hline Methods & Multicentre, randomised, open-label, parallel group. \\
& Duration: up to 6 months. \\
\hline Participants & $\begin{array}{l}131 \text { participants with strong to unbearable tumour pain no longer responsive to NSAIDs. Mean age } 59 \\
\text { years (range } 27 \text { to } 82 \text { ). Male } 66 \% .\end{array}$ \\
\hline
\end{tabular}

Interventions

Tramadol $100 \mathrm{mg}$ modified release every 8 to 12 hours up to $400 \mathrm{mg} / \mathrm{day}, \mathrm{n}=68$. 
Brema 1996 (Continued)

Buprenorphine $0.2 \mathrm{mg}$ sublingual every 6 to 8 hours, $\mathrm{n}=63$.

Outcomes PI: 6-point NRS at baseline and days 7, 14 then monthly.

Type of pain.

PI: 100-mm VAS.

PR: 6-point VRS.

Patient acceptability.

Adverse events.

Withdrawals.

Notes

\section{Risk of bias}

\begin{tabular}{lll}
\hline Bias & Authors' judgement & Support for judgement \\
\hline $\begin{array}{l}\text { Random sequence genera- } \\
\text { tion (selection bias) }\end{array}$ & Unclear risk & "randomisation list"; method of sequence generation not reported. \\
\hline $\begin{array}{l}\text { Allocation concealment } \\
\text { (selection bias) }\end{array}$ & Unclear risk & Method of allocation not reported. \\
\hline $\begin{array}{l}\text { Blinding of participants } \\
\text { and personnel (perfor- } \\
\text { mance bias) }\end{array}$ & High risk & Open-label study. \\
All outcomes & & \\
\end{tabular}

\begin{tabular}{lll}
\hline $\begin{array}{l}\text { Blinding of outcome as- } \\
\text { sessment (detection bias) } \\
\text { All outcomes }\end{array}$ & High risk & Not stated. \\
\hline $\begin{array}{l}\text { Incomplete outcome data } \\
\text { (attrition bias) } \\
\text { All outcomes }\end{array}$ & High risk & $\begin{array}{l}\text { Approximately one third of participants dropped out in each group. Imputa- } \\
\text { tion not mentioned. }\end{array}$ \\
\hline $\begin{array}{l}\text { Selective reporting (re- } \\
\text { porting bias) }\end{array}$ & Low risk & No problems identified. \\
\hline Size & Unclear risk & 131 participants. \\
\hline
\end{tabular}

\section{Leppert 2001}

Methods Randomised, open-label, parallel group.

Duration: 7-day titration, 28 days' stable dose.

Participants 40 participants with moderate to severe cancer pain ( $\mathrm{PI} \geq 45 / 100$, mean at baseline $80 / 100)$, opioid naive. Mean age and sex not reported.

Interventions Tramadol titrated up to $600 \mathrm{mg}$ CR daily, $\mathrm{n}=20$.

Morphine up to $200 \mathrm{mg}$ CR daily, $\mathrm{n}=20$. 
Medication supplied as standard release formulations during titration to $\mathrm{PI}<50 / 100$ or $\leq$ moderate, then doses converted to modified release.

\begin{tabular}{|c|c|c|}
\hline Outcomes & $\begin{array}{l}\text { PI: VAS and 5-point VRS. } \\
\text { PR: 5-point VRS. } \\
\text { Participant preference. } \\
\text { QoL: EORTC. } \\
\text { Adverse events. } \\
\text { Withdrawals. }\end{array}$ & \\
\hline \multicolumn{3}{|l|}{ Notes } \\
\hline \multicolumn{3}{|l|}{ Risk of bias } \\
\hline Bias & Authors' judgement & Support for judgement \\
\hline $\begin{array}{l}\text { Random sequence genera- } \\
\text { tion (selection bias) }\end{array}$ & Unclear risk & "List of random assignment prepared by Statistical Dept." \\
\hline $\begin{array}{l}\text { Allocation concealment } \\
\text { (selection bias) }\end{array}$ & Unclear risk & Method of allocation not reported. \\
\hline $\begin{array}{l}\text { Blinding of participants } \\
\text { and personnel (perfor- } \\
\text { mance bias) } \\
\text { All outcomes }\end{array}$ & High risk & Open-label study. \\
\hline $\begin{array}{l}\text { Blinding of outcome as- } \\
\text { sessment (detection bias) } \\
\text { All outcomes }\end{array}$ & High risk & Not stated. \\
\hline $\begin{array}{l}\text { Incomplete outcome data } \\
\text { (attrition bias) } \\
\text { All outcomes }\end{array}$ & Low risk & No problems identified. \\
\hline $\begin{array}{l}\text { Selective reporting (re- } \\
\text { porting bias) }\end{array}$ & Low risk & No problems identified. \\
\hline Size & High risk & 40 participants in cross-over. \\
\hline
\end{tabular}

\section{Leppert 2010}

$\begin{array}{ll}\text { Methods } & \text { Single centre, randomised, open-label, cross-over study. } \\ & \text { Duration: } 2 \times 7 \text {-day treatment periods; no washout period. }\end{array}$

Participants $\begin{aligned} & 40 \text { participants with cancer pain of moderate intensity }(\geq 40 / 100) \text { with non-opioid therapy, opioid } \\ & \text { naive. Mean age } 70 \text { years. Male } 37 \% \text { of completers. }\end{aligned}$

Interventions Tramadol titrated up to maximum $600 \mathrm{mg}$ CR daily.

Dihydrocodeine titrated up to maximum $360 \mathrm{mg}$ CR daily. 
Dose titrated to effect $(\mathrm{PI}<40 / 100$ or decrease by $\geq 20 / 100$. Previous treatment with NSAIDs, paracetamol, metamizole allowed.

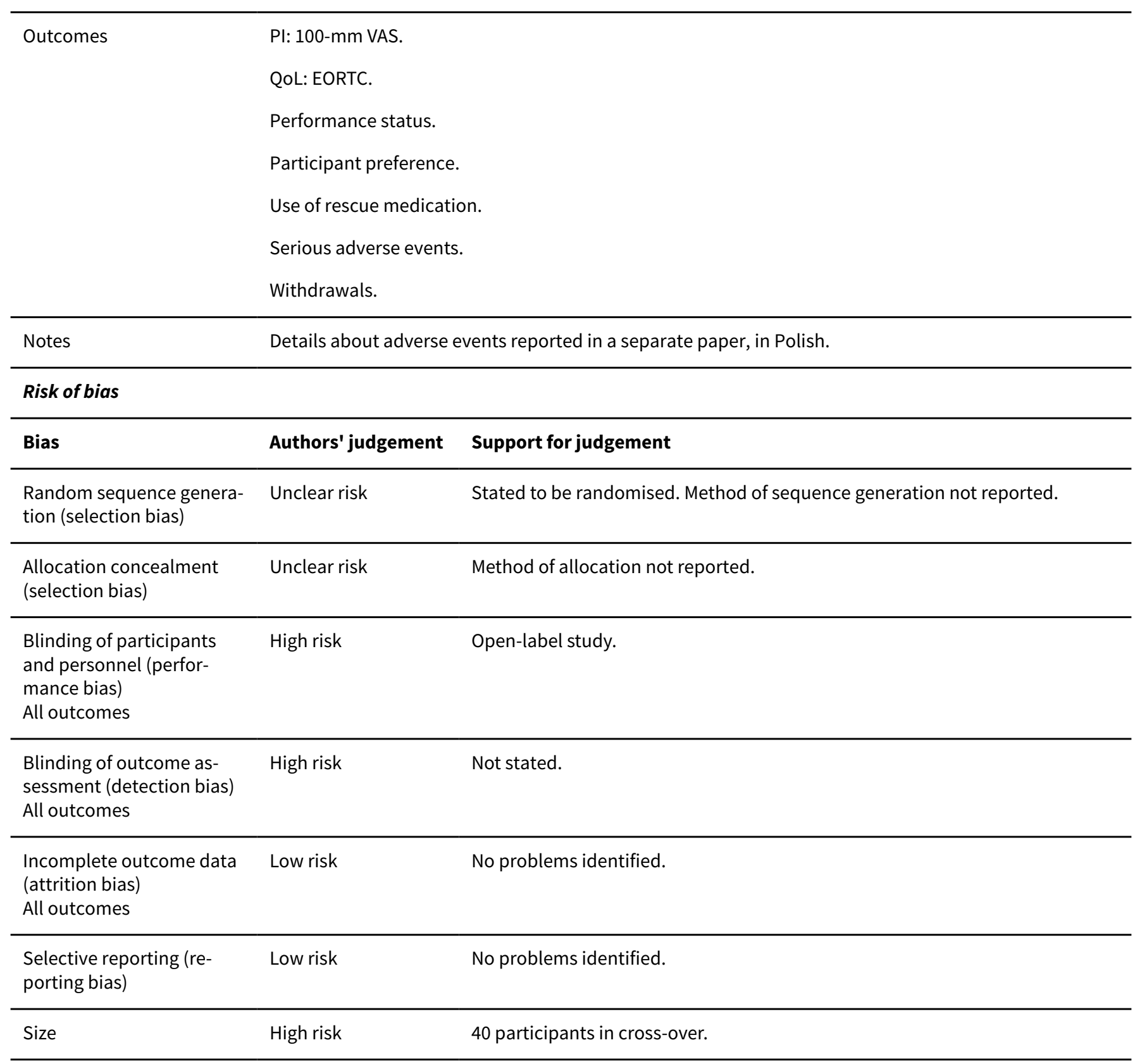

\section{Luben 1994}

\begin{tabular}{ll}
\hline Methods & Randomised, double-blind, parallel group. \\
& Duration: 4 weeks. \\
\hline Participants & $\begin{array}{l}71 \text { participants with cancer pain from various sites; } 48 \text { with metastases. Mean age } 63 \text { years. Sex not re- } \\
\text { ported. }\end{array}$ \\
\hline Interventions & Tramadol $50 \mathrm{mg} 4$ times daily, $\mathrm{n}=36$.
\end{tabular}


Flupirtine $100 \mathrm{mg} 4$ times daily, $\mathrm{n}=35$.

Dose could be increased to up to 6 times daily if needed.

PR: 5-point VRS.
Participants with $\geq 1 / 5$ and $\geq 2 / 5$ point change in PI.
Use of rescue medication.
Clinician global impression of change.
Adverse events.
Withdrawals.

Notes

\section{Risk of bias}

\begin{tabular}{lll}
\hline Bias & Authors' judgement & Support for judgement \\
\hline $\begin{array}{l}\text { Random sequence genera- } \\
\text { tion (selection bias) }\end{array}$ & Unclear risk & Stated to be randomised. Method of sequence generation not reported. \\
\hline $\begin{array}{l}\text { Allocation concealment } \\
\text { (selection bias) }\end{array}$ & Unclear risk & Method of allocation not reported. \\
\hline $\begin{array}{l}\text { Blinding of participants } \\
\begin{array}{l}\text { and personnel (perfor- } \\
\text { mance bias) }\end{array}\end{array}$ & Low risk & Double blind with identical capsules. \\
All outcomes & &
\end{tabular}

\begin{tabular}{|c|c|c|}
\hline $\begin{array}{l}\text { Blinding of outcome as- } \\
\text { sessment (detection bias) } \\
\text { All outcomes }\end{array}$ & High risk & Not stated. \\
\hline $\begin{array}{l}\text { Incomplete outcome data } \\
\text { (attrition bias) } \\
\text { All outcomes }\end{array}$ & Low risk & No problems identified. \\
\hline $\begin{array}{l}\text { Selective reporting (re- } \\
\text { porting bias) }\end{array}$ & Low risk & No problems identified. \\
\hline Size & High risk & 36 in tramadol group, 35 in flupirtine group. \\
\hline
\end{tabular}

\section{Mercadante 2005}

Methods Randomised, double-blind, double-dummy, cross-over study.

Duration: 2 treatment periods of 3 days; no washout described.

\begin{tabular}{ll}
\hline Participants & $\begin{array}{l}60 \text { participants with moderate to severe cancer pain }(\geq 4 / 10, \text { baseline PI } 7 / 10) \text {, unresponsive to non-opi- } \\
\text { oid drugs, non-neuropathic in origin. Mean age } 66 \text { years. Male } 40 \% .\end{array}$ \\
\hline Interventions & Oral tramadol $100 \mathrm{mg}$ twice daily. \\
& Rectal tramadol $100 \mathrm{mg}$ twice daily.
\end{tabular}




Putcomes 0 to 10 NRS and 4-point VRS.
PR: 0 to 10 NRS.
Symptom severity: 4-point VRS.
Quality of sleep.
Participant satisfaction.
Participant preference.
Adverse events.
Withdrawals.

\section{Notes}

\section{Risk of bias}

\begin{tabular}{|c|c|c|}
\hline Bias & Authors' judgement & Support for judgement \\
\hline $\begin{array}{l}\text { Random sequence genera- } \\
\text { tion (selection bias) }\end{array}$ & Unclear risk & Stated to be randomised. Method of sequence generation not reported. \\
\hline $\begin{array}{l}\text { Allocation concealment } \\
\text { (selection bias) }\end{array}$ & Unclear risk & Method of allocation not reported. \\
\hline $\begin{array}{l}\text { Blinding of participants } \\
\text { and personnel (perfor- } \\
\text { mance bias) } \\
\text { All outcomes }\end{array}$ & Low risk & $\begin{array}{l}\text { Double-dummy method described, but detail of blinding not described - } \\
\text { judged low risk. }\end{array}$ \\
\hline $\begin{array}{l}\text { Blinding of outcome as- } \\
\text { sessment (detection bias) } \\
\text { All outcomes }\end{array}$ & High risk & Not stated. \\
\hline $\begin{array}{l}\text { Incomplete outcome data } \\
\text { (attrition bias) } \\
\text { All outcomes }\end{array}$ & High risk & $\begin{array}{l}\text { Imputation not mentioned - analyses for participants who completed } \geq 1 \text { cycle } \\
(50) \text { and cross-over (44). }\end{array}$ \\
\hline $\begin{array}{l}\text { Selective reporting (re- } \\
\text { porting bias) }\end{array}$ & High risk & Outcomes were reported without supporting data. \\
\hline Size & High risk & 60 randomised in cross-over, but $<50$ completed and provided data. \\
\hline
\end{tabular}

\section{Rodriguez 2007}

Methods Multicentre, randomised, double-blind, parallel group.

Duration: 3 weeks.

Participants 177 participants with moderate or severe cancer pain (baseline PI 7/10). Mean age 60 years. Male 50\%.

Interventions Tramadol $200 \mathrm{mg}$ daily, $\mathrm{n}=56$.


Rodriguez 2007 (Continued)

Paracetamol $2500 \mathrm{mg}+$ codeine $150 \mathrm{mg}$ daily, $\mathrm{n}=59$.

Paracetamol 2500 + hydrocodone 25 mg daily, $\mathrm{n}=62$.

Antidepressants or anticonvulsants for neuropathic pain allowed unchanged.

\begin{tabular}{ll}
\hline Outcomes & PI: 100-mm VAS. \\
Participants with "at least some" PR. \\
Adverse events.
\end{tabular}

Notes

\section{Risk of bias}

\begin{tabular}{|c|c|c|}
\hline Bias & Authors' judgement & Support for judgement \\
\hline $\begin{array}{l}\text { Random sequence genera- } \\
\text { tion (selection bias) }\end{array}$ & Low risk & "randomly assigned according to a computer generated schedule." \\
\hline $\begin{array}{l}\text { Allocation concealment } \\
\text { (selection bias) }\end{array}$ & Unclear risk & Method of allocation not reported. \\
\hline $\begin{array}{l}\text { Blinding of participants } \\
\text { and personnel (perfor- } \\
\text { mance bias) } \\
\text { All outcomes }\end{array}$ & Unclear risk & $\begin{array}{l}\text { "Drug distribution was blinded with the drugs packaged in identical contain- } \\
\text { ers" with "appropriate number of tablets", but no indication of whether tablets } \\
\text { were distinguishable. }\end{array}$ \\
\hline $\begin{array}{l}\text { Blinding of outcome as- } \\
\text { sessment (detection bias) } \\
\text { All outcomes }\end{array}$ & High risk & Not stated. \\
\hline $\begin{array}{l}\text { Incomplete outcome data } \\
\text { (attrition bias) } \\
\text { All outcomes }\end{array}$ & Low risk & No problems identified. \\
\hline $\begin{array}{l}\text { Selective reporting (re- } \\
\text { porting bias) }\end{array}$ & Low risk & No problems identified. \\
\hline Size & Unclear risk & 56 to 62 participants per group. \\
\hline
\end{tabular}

Wilder-Smith 1994

$\begin{array}{ll}\text { Methods } & \text { Randomised, double-blind, cross-over study. } \\ \text { Duration: } 2 \text { treatment periods of } 4 \text { days, no washout period. }\end{array}$

\begin{tabular}{ll}
\hline Participants & 20 participants with 'strong pain' due to cancer (metastatic). Mean age 55 years. \\
\hline Interventions & Tramadol solution $5 \%$. Initial dose $50 \mathrm{mg} 6$ times daily. \\
Morphine $1 \%$ solution. Initial dose $16 \mathrm{mg} 6$ times daily. \\
Same dose used for rescue medication, then added to daily dose the following day.
\end{tabular}

Outcomes

PI: 5-point VRS. 
Wilder-Smith 1994 (Continued)

Participant symptom control (preference).

Adverse events.

Withdrawals.

Notes

\section{Risk of bias}

\begin{tabular}{|c|c|c|}
\hline Bias & Authors' judgement & Support for judgement \\
\hline $\begin{array}{l}\text { Random sequence genera- } \\
\text { tion (selection bias) }\end{array}$ & Unclear risk & Stated to be randomised. Method of sequence generation not reported. \\
\hline $\begin{array}{l}\text { Allocation concealment } \\
\text { (selection bias) }\end{array}$ & Unclear risk & Method of allocation not reported. \\
\hline $\begin{array}{l}\text { Blinding of participants } \\
\text { and personnel (perfor- } \\
\text { mance bias) } \\
\text { All outcomes }\end{array}$ & Low risk & $\begin{array}{l}\text { "The two solutions were adapted, to taste, smell and look identically and were } \\
\text { then filled into coded drop dispensers with standardised pipettes by the hospi- } \\
\text { tal pharmacy." }\end{array}$ \\
\hline $\begin{array}{l}\text { Blinding of outcome as- } \\
\text { sessment (detection bias) } \\
\text { All outcomes }\end{array}$ & Low risk & $\begin{array}{l}\text { "The two solutions were adapted, to taste, smell and look identically and were } \\
\text { then filled into coded drop dispensers with standardised pipettes by the hospi- } \\
\text { tal pharmacy." }\end{array}$ \\
\hline $\begin{array}{l}\text { Incomplete outcome data } \\
\text { (attrition bias) } \\
\text { All outcomes }\end{array}$ & Low risk & $\begin{array}{l}\text { No problems identified. Worst observation carried forward for early discontin- } \\
\text { uation. }\end{array}$ \\
\hline $\begin{array}{l}\text { Selective reporting (re- } \\
\text { porting bias) }\end{array}$ & Low risk & No problems identified. \\
\hline Size & High risk & 20 participants in cross-over. \\
\hline
\end{tabular}

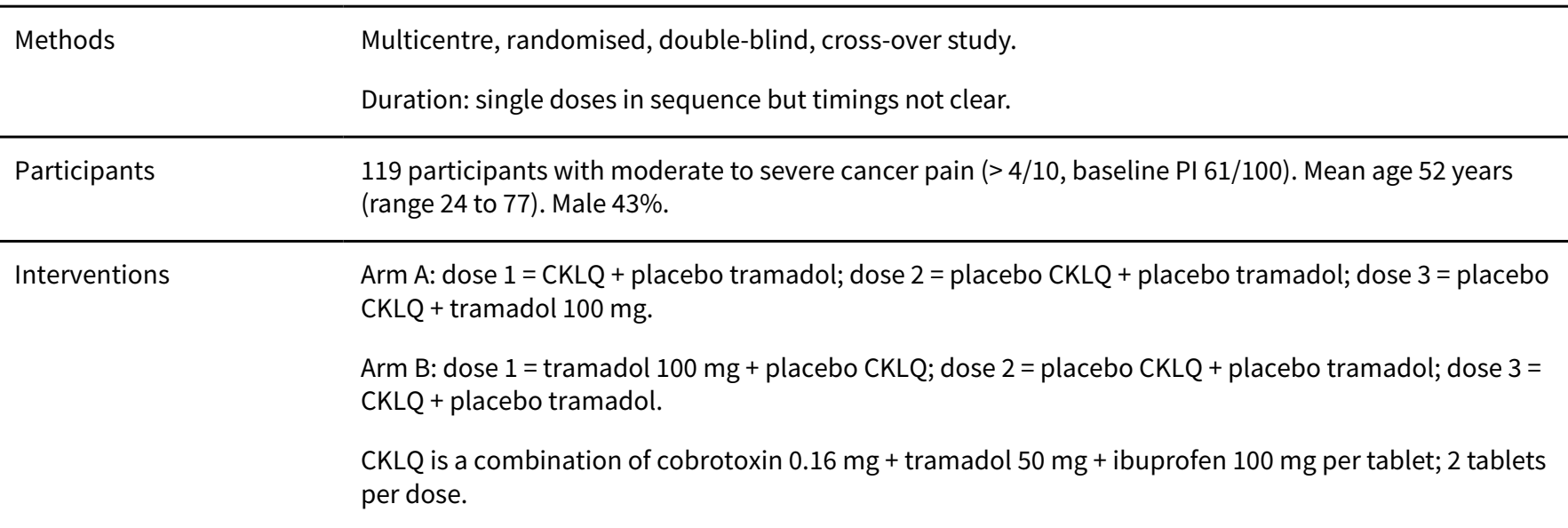

Putcomes $100-m m$ VAS every 10 minutes for 60 minutes.
PI: 4-point VRS.


Xu 2006 (Continued)

Participants with complete relief $(\mathrm{PI}=0 / 100)$.

Participants with partial relief (PI decreased to mild pain, score $\leq 4 / 10$ ).

Participants with no change (PI unchanged or $>4 / 10$ ).

Adverse events.

Withdrawals.

Notes

\section{Risk of bias}

\begin{tabular}{|c|c|c|}
\hline Bias & Authors' judgement & Support for judgement \\
\hline $\begin{array}{l}\text { Random sequence genera- } \\
\text { tion (selection bias) }\end{array}$ & Low risk & $\begin{array}{l}\text { Computer generated randomisation. "Assignment written on a card and put } \\
\text { into a sealed envelope." }\end{array}$ \\
\hline $\begin{array}{l}\text { Allocation concealment } \\
\text { (selection bias) }\end{array}$ & Unclear risk & Method of allocation not reported. \\
\hline $\begin{array}{l}\text { Blinding of participants } \\
\text { and personnel (perfor- } \\
\text { mance bias) } \\
\text { All outcomes }\end{array}$ & Low risk & $\begin{array}{l}\text { Double-dummy design. "The placebo was formulated to be identical in color, } \\
\text { taste, texture and package". All doses were } 2 \text { tablets of each intervention. }\end{array}$ \\
\hline $\begin{array}{l}\text { Blinding of outcome as- } \\
\text { sessment (detection bias) } \\
\text { All outcomes }\end{array}$ & Low risk & $\begin{array}{l}\text { Double-dummy design. "The placebo was formulated to be identical in color, } \\
\text { taste, texture and package". All doses were } 2 \text { tablets of each intervention. }\end{array}$ \\
\hline $\begin{array}{l}\text { Incomplete outcome data } \\
\text { (attrition bias) } \\
\text { All outcomes }\end{array}$ & Low risk & No problems identified. \\
\hline $\begin{array}{l}\text { Selective reporting (re- } \\
\text { porting bias) }\end{array}$ & Low risk & No problems identified. \\
\hline Size & Unclear risk & Group sizes 59 and 60 participants. \\
\hline
\end{tabular}

CR: controlled release; EORTC: European Organisation for Research and Treatment of Cancer; $n$ : number of participants per treatment arm; NRS: numerical rating scale; NSAID: nonsteroidal anti-inflammatory drug; PI: pain intensity; PR: pain relief; QoL: quality of life; VAS: visual analogue scale; VRS: verbal rating scale.

Characteristics of excluded studies [ordered by study ID]

\begin{tabular}{ll}
\hline Study & Reason for exclusion \\
\hline Arbaiza 2007 & Neuropathic pain in people with cancer. \\
\hline Marinangeli 2007 & Tramadol added to fentanyl. \\
\hline Tassinari 2011 & Systematic review. \\
\hline Yavuz 2004 & Tramadol for postoperative pain in gynaecological cancer pain. \\
\hline
\end{tabular}




\section{AP PEN DICES}

\section{Appendix 1. MEDLINE search strategy}

1. exp Pain/ (328885)

2. pain.tw. (411189)

3. 1 or 2 (552420)

4. exp Neoplasms/ (2827457)

5. (cancer ${ }^{\star}$ or neoplas* or tumo* or carcinoma* or hodgkin* or nonhodgkin* or adenocarcinoma* or leuk?emia* or metasta* or malignan* or lymphoma* or sarcoma* or melanoma* or myeloma* or oncolog*).tw. (2670775)

6. 4 or $5(3344191)$

7. 3 and 6 (84189)

8. Tramadol/ (2467)

9. tramadol.mp. (3383)

10.k-315.mp. (10)

11.8 or 9 or $10(3393)$

12.Acetaminophen/ (15188)

13. (acetaminophen or paracetamol or Panadol or Tylenol).mp. [mp=title, abstract, original title, name of substance word, subject heading word, keyword heading word, protocol supplementary concept word, rare disease supplementary concept word, unique identifier] (20846)

14.12 or $13(20846)$

15.11 and 14 (519)

16.7 and 11 (248)

17.7 and $15(50)$

18.16 or 17 (248)

19.randomized controlled trial.pt. (414789)

20.controlled clinical trial.pt. (90619)

21.randomized.ab. (311705)

22.placebo.ab. (158104)

23.drug therapy.fs. (1852228)

24.randomly.ab. (220170)

25.trial.ab. (322366)

26.groups.ab. (1389663)

27.19 or 20 or 21 or 22 or 23 or 24 or 25 or 26 (3518483)

28.exp animals/ not humans.sh. (4236009)

29.27 not 28 (2997289)

30.18 and 29 (202)

\section{Appendix 2. CENTRAL search strategy}

\#1 MESH DESCRIPTOR Pain EXPLODE ALL TREES 32311

\#2 pain:TI,AB,KY 83891

\#3 \#1 OR \#2 88757

\#4 MESH DESCRIPTOR Neoplasms EXPLODE ALL TREES 46196

\#5 ((cancer ${ }^{\star}$ or neoplas* or tumo* or carcinoma* or hodgkin* or nonhodgkin* or adenocarcinoma* or leuk?emia* or metasta* or malignan* or lymphoma* or sarcoma* or melanoma* or myeloma* or oncolog*)):TI,AB,KY 109552

\#6 \#4 AND \#5 44635

\#7 \#3 AND \#6 3519

\#8 MESH DESCRIPTOR Tramadol EXPLODE ALL TREES 741

\#9 tramadol:TI,AB,KY 2128

Tramadol with or without paracetamol (acetaminophen) for cancer pain (Review) 
\#10 k-315:TI,AB,KY 1

\#11 \#8 OR \#9 OR \#10 2129

\#12 MESH DESCRIPTOR Acetaminophen EXPLODE ALL TREES 1873

\#13 ((acetaminophen or paracetamol or Panadol or Tylenol)):TI,AB,KY 5644

\#14 \#12 OR \#13 5644

\#15 \#11 AND \#14 451

\#16 \#7 AND \#11 53

\#17 \#7 AND \#15 11

\#18 \#16 OR \#17 53

\section{Appendix 3. Embase search strategy}

1 exp Pain/ (1002612)

2 pain.tw. (678037)

31 or $2(1206185)$

4 exp Neoplasm/ (3737489)

5 (cancer* or neoplas* or tumo* or carcinoma* or hodgkin* or nonhodgkin* or adenocarcinoma* or leuk? emia* or metasta* or malignan* or lymphoma* or sarcoma* or melanoma* or myeloma* or oncolog*).tw. (3818206)

64 or 5 (4616390)

73 and 6 (246270)

8 Tramadol/ (15612)

9 tramadol.mp. (16228)

10 k-315.mp. (15)

118 or 9 or 10 (16240)

12 Paracetamol/ (73077)

13 (acetaminophen or paracetamol or Panadol or Tylenol).mp. [mp=title, abstract, heading word, drug trade name, original title, device manufacturer, drug manufacturer, device trade name, keyword] (77856)

1412 or $13(77856)$

1511 and 14 (5629)

167 and $11(2044)$

177 and 15 (896)

1816 or 17 (2044)

19 random\$.tw. (1115183)

20 factorial\$.tw. (28388)

21 crossover\$.tw. (58689)

22 cross over\$.tw. (26130)

23 cross-over\$.tw. $(26130)$

24 placebo\$.tw. (243094)

Tramadol with or without paracetamol (acetaminophen) for cancer pain (Review) 
25 (doubl\$ adj blind\$).tw. (171477)

26 (singl\$ adj blind\$).tw. (18123)

27 assign\$.tw. (294263)

28 allocat\$.tw. (107047)

29 volunteer\$.tw. (210635)

30 Crossover Procedure/ (48290)

31 double-blind procedure.tw. (235)

32 Randomized Controlled Trial/ (416205)

33 Single Blind Procedure/ (22773)

34 or/19-33 (1740101)

35 (animal/ or nonhuman/) not human/ (5092256)

3634 not $35(1546286)$

3718 and $36(334)$

\section{Appendix 4. LILACS search strategy}

pain [Words] and (cancer\$ or neoplas\$ or tumo\$ or carcinoma\$ or hodgkin\$ or nonhodgkin\$ or adenocarcinoma\$ or leukemia\$ or leukaemia\$ or metasta or malignan $\$$ or lymphoma or sarcoma\$ or melanoma\$ or myeloma or oncolog\$) [Words] and tramadol or $\mathrm{k}-315$ [Words]

\section{Appendix 5. GRADE: criteria for assigning grade of evidence}

The GRADE system uses the following criteria for assigning a quality level to a body of evidence (Chapter 12, Higgins 2011).

- High: randomised trials; or double-upgraded observational studies.

- Moderate: downgraded randomised trials; or upgraded observational studies.

- Low: double-downgraded randomised trials; or observational studies.

- Very low: triple-downgraded randomised trials; or downgraded observational studies; or case series/case reports.

Factors that may decrease the quality level of a body of evidence are:

- limitations in the design and implementation of available studies suggesting high likelihood of bias;

- indirectness of evidence (indirect population, intervention, control, outcomes);

- unexplained heterogeneity or inconsistency of results (including problems with subgroup analyses);

- imprecision of results (wide confidence intervals);

- high probability of publication bias.

Factors that may increase the quality level of a body of evidence are:

- large magnitude of effect;

- all plausible confounding would reduce a demonstrated effect or suggest a spurious effect when results show no effect;

- dose-response gradient.

\section{WHAT'S NEW}

\begin{tabular}{lll}
\hline Date & Event & Description \\
\hline 18 February 2020 & Amended & Clarification added to Declarations of interest. \\
\hline 6 November 2018 & Review declared as stable & See Published notes. \\
\hline
\end{tabular}




\section{HISTORY}

Protocol first published: Issue 1, 2017

Review first published: Issue 5, 2017

\begin{tabular}{lll}
\hline Date & Event & Description \\
\hline 28 May 2019 & Amended & Contact details updated. \\
\hline
\end{tabular}

\section{CONTRIBUTIONS OF AUTHORS}

\begin{tabular}{|c|c|}
\hline Draft the protocol & PW \\
\hline \multirow[t]{2}{*}{ Develop and run the search strategy } & PW, SD \\
\hline & $\begin{array}{l}\text { PaPaS Information Specialist } \\
\text { provided support }\end{array}$ \\
\hline Obtain copies of studies & PW \\
\hline Select which studies to include (2 people) & PW, SD \\
\hline Extract data from studies (2 people) & PW, SD \\
\hline Enter data into RevMan & PW, SD \\
\hline Carry out the analysis & PW, SD \\
\hline Interpret the analysis & All \\
\hline Draft the final review & PW, RAM \\
\hline Update the review & PW \\
\hline
\end{tabular}

\section{DECLARATIONS OF INTEREST}

PW: none known.

SD: none known.

RAM has received grant support from Grünenthal relating to individual patient level analyses of trial data regarding tapentadol in osteoarthritis and back pain (2015). He has received honoraria for attending boards with Menarini concerning methods of analgesic trial design (2014), with Novartis (2014) about the design of network meta-analyses, and RB on understanding pharmacokinetics of drug uptake (2015). He has received honoraria from Omega Pharma (2016) and Futura Pharma (2016) for providing advice on trial and data analysis methods.

This review was identified in a 2019 audit as not meeting the current definition of the Cochrane Commercial Sponsorship policy. At the time of its publication it was compliant with the interpretation of the existing policy. As with all reviews, new and updated, at update this review will be revised according to 2020 policy update. 


\section{SOURCES OF SUPPORT}

\section{Internal sources}

- Oxford Pain Relief Trust, UK.

General institutional support

\section{External sources}

- The National Institute for Health Research (NIHR), UK.

NIHR Cochrane Programme Grant: 13/89/29 - Addressing the unmet need of chronic pain: providing the evidence for treatments of pain

\section{DIFFERENCES BETWEEN PROTOCOL AND REVIEW}

There are several differences between the protocol and the review.

We amended secondary outcomes as a response to what was actually reported: 'Serious adverse events, defined as leading to withdrawal from treatment, including death' and 'Attrition: withdrawals due to lack of efficacy or adverse events.'

We updated GRADE wording to conform to more recent standards.

We amended outcomes to conform to more recent reviews in this series. The protocol planned to include: number of participants with pain reduction of $30 \%$ or greater from baseline, number of participants with pain reduction of $50 \%$ or greater from baseline, and adverse events in the 'Summary of findings' table. This has become 'number of participants with pain reduction of 30\% or 50\% or greater, participants with pain no worse than mild, and PGIC of much improved or very much improved'. We have also included serious adverse events, other adverse events, and withdrawals due to lack of efficacy or adverse events.

We made minor changes to the search strategy. We added a search of LILACS. The protocol incorrectly stated that we planned to contact experts in the field for unpublished and ongoing trials. This was not part of the plan, and was not done.

We added 'duration of study' to the planned subgroups.

We added Selective reporting (reporting bias) to the 'Risk of bias' assessment.

\section{NOTES}

A restricted search in November 2018 did not identify any potentially relevant studies. Therefore, this review has now been stabilised for three years following discussion with the authors and editors. If appropriate, we will update the review if new evidence likely to change the conclusions is published, or if standards change substantially which necessitate major revisions.

\section{N DEX TERMS}

\section{Medical Subject Headings (MeSH)}

Acetaminophen [adverse effects] [ ${ }^{*}$ therapeutic use]; Analgesics, Non-Narcotic [adverse effects] [ ${ }^{*}$ therapeutic use]; Analgesics, Opioid [adverse effects] [*therapeutic use]; Cancer Pain [*drug therapy]; Drug Therapy, Combination; Randomized Controlled Trials as Topic; Tramadol [adverse effects] [*therapeutic use]

\section{MeSH check words}

Adult; Aged; Humans; Middle Aged; Young Adult 